\title{
Lawns in Cities: From a Globalised Urban Green Space Phenomenon to Sustainable Nature-Based Solutions
}

\author{
Maria Ignatieva ${ }^{1, *} \mathbb{0}$, Dagmar Haase ${ }^{2,3} \mathbb{D}$, Diana Dushkova ${ }^{2}$ and Annegret Haase 4 \\ 1 School of Design, The University of Western Australia, 35 Stirling Highway, Perth, WA 6001, Australia \\ 2 Department of Geography, Humboldt University Berlin, Unter den Linden 6, 10099 Berlin, Germany; \\ dagmar.haase@ufz.de (D.H.); diana.dushkova@geo.hu-berlin.de (D.D.) \\ 3 Department of Comp. Landscape Ecology, Helmholtz Centre for Environmental Research-UFZ, \\ Permoserstr. 15, 04318 Leipzig, Germany \\ 4 Department of Urban and Environmental Sociology, Helmholtz Centre for Environmental Research-UFZ, \\ Permoserstr. 15, 04318 Leipzig, Germany; annegret.haase@ufz.de \\ * Correspondence: maria.ignatieva@uwa.edu.au; Tel.: +61-8-6488-6000
}

Received: 29 January 2020; Accepted: 27 February 2020; Published: 2 March 2020

\begin{abstract}
This opinion paper discusses urban lawns, the most common part of open green spaces and urban green infrastructures. It highlights both the ecosystem services and also disservices provided by urban lawns based on the authors' experience of working within interdisciplinary research projects on lawns in different cities of Europe (Germany, Sweden and Russia), New Zealand (Christchurch), USA (Syracuse, NY) and Australia (Perth). It complements this experience with a detailed literature review based on the most recent studies of different biophysical, social, planning and design aspects of lawns. We also used an international workshop as an important part of the research methodology. We argue that although lawns of Europe and the United States of America are now relatively well studied, other parts of the world still underestimate the importance of researching lawns as a complex ecological and social phenomenon. One of the core objectives of this paper is to share a paradigm of nature-based solutions in the context of lawns, which can be an important step towards finding resilient sustainable alternatives for urban green spaces in the time of growing urbanisation, increased urban land use competition, various user demands and related societal challenges of the urban environment. We hypothesise that these solutions may be found in urban ecosystems and various local native plant communities that are rich in species and able to withstand harsh conditions such as heavy trampling and droughts. To support the theoretical hypothesis of the relevance of nature-based solutions for lawns we also suggest and discuss the concept of two natures-different approaches to the vision of urban nature, including the understanding and appreciation of lawns. This will help to increase the awareness of existing local ecological approaches as well as an importance of introducing innovative landscape architecture practices. This article suggests that there is a potential for future transdisciplinary international research that might aid our understanding of lawns in different climatic and socio-cultural conditions as well as develop locally adapted (to environmental conditions, social needs and management policies) and accepted nature-based solutions.
\end{abstract}

Keywords: lawns; ecosystem services and disservices; nature-based solutions for lawns; alternative to lawns; sustainable lawns; two natures

\section{Introduction}

The recent worldwide changes in climate, including heatwaves and long drought periods, has resulted in the degradation of urban green spaces. Regardless of climatic conditions, water availability 
or cultural traditions, lawns are the most common elements of green city spaces across the globe, covering up to $50-70 \%$ of urban green areas [1]. In German cities like Leipzig, public park lawns cover at least 50\% [2]. Similarly, in Sweden, lawns make up 50\% of urban green areas [3]. Interestingly, Chinese cities are currently one of the largest users of lawns [4] and in the US, lawn (often called turf or grass) surfaces dominate urban and suburban landscapes and cover almost $2 \%$ of the country's terrestrial area [5]. The total area under turf in Australia is around 4400 hectares making up an average of $11 \%$ of the total areas of cities [6].

Lawns are highly recognised and massively prefabricated landscape design element. In many cases, turf is used as the easiest and most cost-effective short-term solution to covering "leftover places" after the demolition of buildings or for the "beautification" of abandoned places [1]. For shrinking cities, lawns act as an interim successional stage after the abandonment or demolition of built structures [7-10]. While urbanisation has led to a dramatic increase in lawn surfaces, these surfaces require significant input of energy and resources and the use of seed mixtures from global lawn nurseries. This has resulted in biological and visual homogenisation of urban environments [11-13].

The recent hot and dry summers in Europe (2017-2019) and severe drought conditions in many other countries around the world-California, Arizona, and Mid-West of USA, Cape Town in South Africa and across Australia-revealed particular issues related to the restrictions of water use [14-16]. Many urban grassy surfaces degrade from trampling and extreme sun or shade exposure, and thus quickly become brownscapes while also losing the ecosystem services that lawns typically perform $[7,8]$.

One of the reactions to lawn degradation is the use of synthetic lawns instead of living grassed surfaces. Along with the growing contamination of aquatic habitats from plastic particles [17], the use of artificial lawns is contributing to the pollution of urban environments. A significant volume of polymer granules and synthetic grass fragments are introduced by water and wind into the environment each year and need to be better recognised as a form of microplastic pollution affecting soil, waterways, and ultimately the ocean $[18,19]$. These problems have highlighted the need to investigate and develop alternative, more resistant sustainable solutions for lawns that withstand impending climate change conditions and, at the same time, create environmentally friendly and aesthetically acceptable urban green open spaces.

In this article, we analyse the ecosystem services and disservices created by lawns. We further discuss existing alternative visions for urban lawns from different countries in both the northern and southern hemispheres. In this study, we use the concept of nature-based solution as an important foundation for searching of sustainable lawns. We accept the definition of nature-based solutions as proposed by European Commission [20] and Raymond et al. [21], that they are "... actions and solutions to societal challenges which are inspired and supported by or copied from nature and provide at the same time multiple environmental, social, economic co-benefits such as the improvement of place attractiveness, of health and quality of life, creation of green jobs, etc." Our vision of nature-based solutions is grounded in the acceptance and respect of local peculiarities from country to country and is founded on a complex approach which includes biological, planning and design elements, provide social and economic benefits (such as the improvement of place attractiveness, of health and quality of life, creation of green jobs, etc.) as well as sustainable management and stewardship that is driven by municipalities.

Despite the universal adoption of lawns, there are a variety of lawn types and differences in technological peculiarities of construction and management regimes. These types are rooted in the history of the introduction of lawns and are connected to climatic, economic, and cultural conditions, as well as to specific land use and landscape design traditions [1]. There is an urgent need to explore nature-based solutions in order to better adapt lawns to current changing climatic conditions within particular geographical zones, local cultural perceptions and expectations, social wants and needs, and economic opportunities. 


\section{Conceptual Analytical Framework}

This opinion paper discusses the phenomenon of lawns based on the authors' long-term project experience of working within the interdisciplinary research projects on lawns in different cities of Europe (Leipzig and Berlin in Germany, Uppsala, Malmo and Gothenburg in Sweden, Moscow, St. Petersburg, Kirovsk and Apatity in Russia), New Zealand (Christchurch), USA (Syracuse, NY) and Australia (Perth). These projects provided the opportunity to obtain and analyse large amounts of qualitative and quantitative data as well as to test some alternative nature-based and locally adapted solutions related to lawns.

The detailed conceptual analytical framework of this article is presented in Figure 1. To identify key questions related to existing lawn research and discover a research gap, we used a literature review based on SCOPUS, ISI Web of Sciences and Google Scholar (Figure 2). We specifically targeted key terms related to the particular ecosystem services and disservices of lawns (analysed in detail in Section 3). The search keywords were "lawn as a habitat", "use of lawns", "lawn as a symbol", "plastic lawn", "heat island mitigation by lawn". To support the theoretical hypothesis of the relevance of nature-based solutions for lawns we also suggest and discuss the concept of two natures-different approaches to the vision of urban nature, including understanding and appreciation of lawns (Section 4). This concept helped us to explain the directions for lawn alternatives and their correlation with local natural and social conditions (Section 5). For lawn alternatives, the choice of case studies and references was based on the analysis of existing projects in which authors had participated (urban meadows, pictorial meadows, woody meadows, use of appropriate native groundcovers in private gardens etc.) or related literature review [22,23]. We prioritised the most recent publications (2011-2019) but also included earlier peer-reviewed works. There were 139 publications related to the key words; 92 publications were included in the final list of references and 47 publications were excluded from the final list. There were two main criteria for exclusion: non-urban areas and if the article did not address one of the key searching aspects (key words). The structural analysis of the literature review used in the paper is presented in Table 1.

\begin{tabular}{|c|c|c|}
\hline PROCESS / RESEARCH STEP & DESCRIPTION / ACTIVITIES & \\
\hline \multirow[t]{3}{*}{ RESEARCH DESIGN } & \multirow{3}{*}{$\begin{array}{l}\text { - Identify the key issues related to lawn research } \\
\text { - Identify the hypothesis } \\
\text { - Reveal the goals, methods (including research tools) used } \\
\text { in the related research and a research gap }\end{array}$} & $\begin{array}{l}\text { Research goal } \\
\text { and research questions }\end{array}$ \\
\hline & & \\
\hline & & $\begin{array}{l}\text { Literature review in SCOPUS, ISI Web } \\
\text { of Sciences, Google Scholar }\end{array}$ \\
\hline $\begin{array}{l}\text { PREMISES FOR } \\
\text { CONDUCTING RESEARCH }\end{array}$ & $\begin{array}{l}\text { Preliminary list for research gaps and suggestions } \\
\text { how they can be covered by the current research } \\
\text { - Developing concept, thinking models and framework }\end{array}$ & $\begin{array}{l}\text { Key issues identified as the main } \\
\text { sections of the research }\end{array}$ \\
\hline \multirow[t]{4}{*}{ ANALYSIS } & \multirow{4}{*}{$\begin{array}{l}\text { - Social, cultural, historical and political embedding } \\
\text { - Natural system and environmental impact } \\
\text { (ecosystem services and disservices) } \\
\text { - Planning and management issues } \\
\text { - Two natures concept related to lawns } \\
\text { - Searching for nature-based alternatives for urban lawns }\end{array}$} & $\begin{array}{l}\text { Analysis of the case study evidence } \\
\text { (own experience in lawn research) }\end{array}$ \\
\hline & & \\
\hline & & $\begin{array}{l}\text { Analysis of the relevant publications } \\
\text { and documents }\end{array}$ \\
\hline & & \\
\hline \multirow[t]{2}{*}{ DISCUSSION } & $\begin{array}{l}\text { - Comparing findings with the existing concepts and results } \\
\text { - Reflect (test) the research hypothesis }\end{array}$ & \multirow{3}{*}{$\begin{array}{l}\text { Lawn experts' workshop: } \\
\text { information sharing and discussion } \\
\text { Contribution to the knowledge base }\end{array}$} \\
\hline & $\begin{array}{l}\text { - Suggest a new concept } \\
\text { - Future directions for research on sustainable lawns }\end{array}$ & \\
\hline CONCLUSION & & \\
\hline & iterdisciplinary research framework & \\
\hline
\end{tabular}

Figure 1. Conceptual framework of this paper. 
To support the theoretical hypothesis of the relevance of nature-based solutions for lawns we also suggest and discuss the concept of two natures-different approaches to the vision of urban nature, including understanding and appreciation of lawns.

We also used a workshop as part of the research methodology. The international lawn experts' workshop "Urban Biodiversity and Nature-Based Design methodology and practical applications for interdisciplinary research" in Berlin on 28-29 November 2019 was organised by the Geography Department of Humboldt University, Berlin. Participants from different scientific background and different part of the globe, who have been dealing with the different aspects of urban lawns and nature-based solutions gathered together, discussed methodology and the future perspectives of lawn research. Thus, this article also provides the theoretical and conceptual foundation for future international and interdisciplinary research project on lawns (Figure 14).

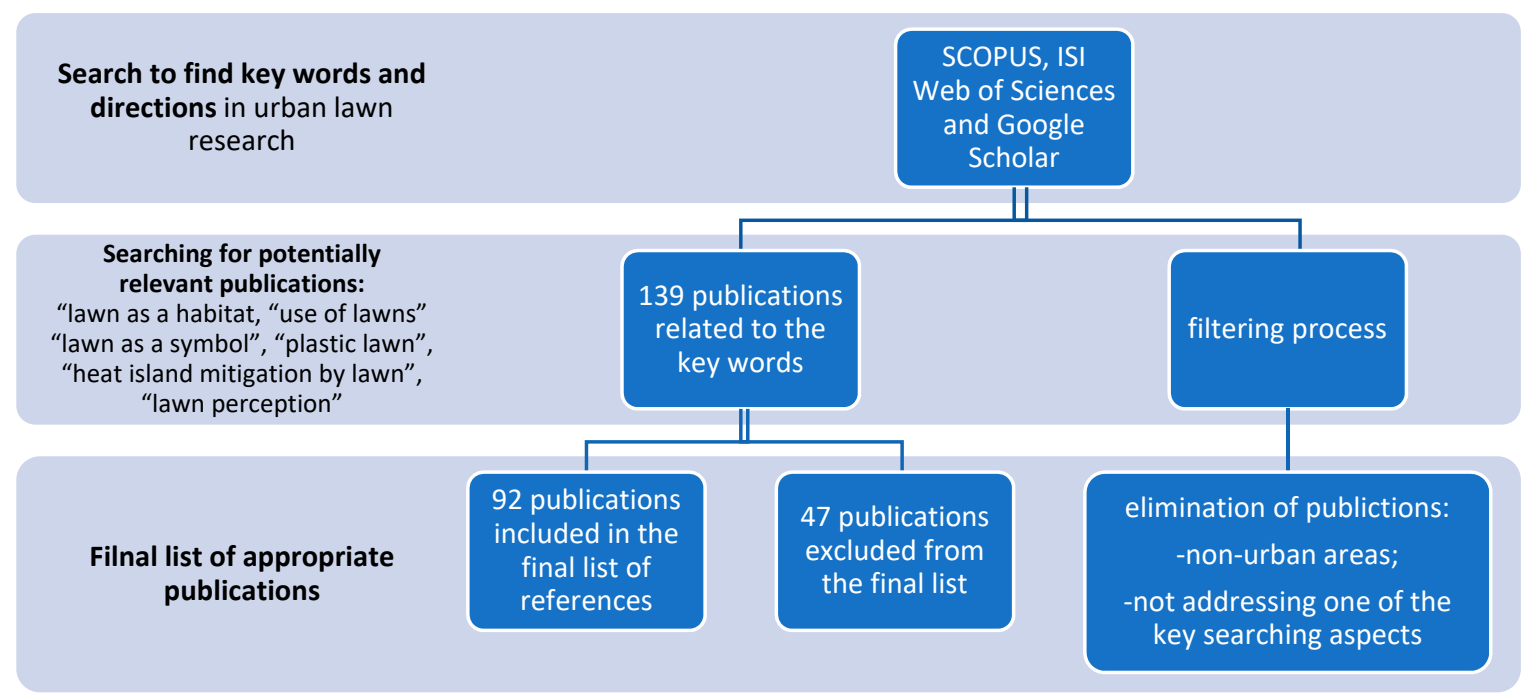

Figure 2. Literature review process.

Table 1. Structural analysis of the literature review used in this paper.

\begin{tabular}{|c|c|c|}
\hline $\begin{array}{c}\text { Category of } \\
\text { Research on Lawn }\end{array}$ & Aspects & References \\
\hline \multirow{4}{*}{$\begin{array}{l}\text { Environmental } \\
\text { aspects of lawns }\end{array}$} & $\begin{array}{l}\text { Estimation of lawn cover } \\
\text { using remote sensing and } \\
\text { earth observation methods }\end{array}$ & $\begin{array}{l}\text { Hedblom et al., } 2017 \text { [3]; Milesi et al., 2005 [24]; Robbins and } \\
\text { Birkenholz, } 2003 \text { [25] }\end{array}$ \\
\hline & $\begin{array}{l}\text { Biodiversity and } \\
\text { vegetation aspects }\end{array}$ & $\begin{array}{l}\text { Gaston et al., } 2005 \text { [26]; Hahs and McDonnell, } 2007 \text { [27]; Lindenmayer } \\
\text { et al., } 2008 \text { [28]; Müller, } 1990 \text { [29]; Stewart et al., } 2009 \text { [30]; Sukopp and } \\
\text { Kowarik, } 1990 \text { [31]; Threlfall et.al., } 2015 \text { [32] }\end{array}$ \\
\hline & $\begin{array}{l}\text { Ecosystem services } \\
\text { provided by lawns }\end{array}$ & $\begin{array}{c}\text { Amani-Beni et al., } 2018 \text { [33]; Armson et al., } 2013 \text { [34]; Beard and Green, } \\
\text { 1994 [35]; Brunton et al., } 2010 \text { [36]; Burgin, } 2016 \text { [37]; Cumming, } 2018 \\
\text { [6]; Fischer et al., } 2013 \text { [38]; Fischer et al., } 2016 \text { [39]; Haase et al., 2014a } \\
\text { [7]; Haase et al., } 2014 b \text { [8]; Johnson, } 2013 \text { [40]; Lele et al., 2013 [41]; } \\
\text { Monteiro, } 2017 \text { [42]; Stirling et al., } 2013 \text { [43]; Thompson and } \\
\text { Kao-Kniffin, } 2017 \text { [5]; Trigger and Mulcock, } 2005 \text { [44]; Wang et al., } \\
2016 \text { [45]; Wastian et al., } 2004 \text { [46] }\end{array}$ \\
\hline & $\begin{array}{l}\text { Ecosystem disservices } \\
\text { provided by lawns: }\end{array}$ & $\begin{array}{l}\text { Brunton et al., } 2010 \text { [36]; Burgin, } 2016 \text { [37]; Campagne et al., } 2018 \text { [47]; } \\
\text { Cumming, } 2018 \text { [6]; Döhren and Haase, } 2015 \text { [48]; Dunn, } 2010 \text { [49]; } \\
\text { Ignatieva and Hedblom, } 2018 \text { [1]; Lyytimäki, 2013 [50]; McKinney, } \\
2006 \text { [12]; Milesi et al., } 2005 \text { [24]; Müller and Sukopp, } 2016 \text { [51]; Priest } \\
\text { et al., 2000 [52]; Runola et al., } 2013 \text { [53]; Shackleton et al., 2016 [54]; } \\
\text { Schapel et al., } 2018 \text { [55]; Sharma et al., 1996 [56]; Stirling et al., 2013 } \\
\text { [43]; Trigger and Mulcock, } 2005 \text { [44]; Wheeler et al., 2017 [13] }\end{array}$ \\
\hline
\end{tabular}


Table 1. Cont.

\begin{tabular}{|c|c|c|}
\hline $\begin{array}{c}\text { Category of } \\
\text { Research on Lawn }\end{array}$ & Aspects & References \\
\hline \multirow[t]{3}{*}{$\begin{array}{l}\text { Social aspects of } \\
\text { lawns }\end{array}$} & $\begin{array}{l}\text { Public perception, attitude } \\
\text { and preferences }\end{array}$ & $\begin{array}{c}\text { Elgizawy, } 2016 \text { [57]; Han et al., } 2013 \text { [58]; Ignatieva, } 2017 \text { [22]; Jenkins, } \\
1994 \text { [59]; Pisa, } 2019 \text { [60]; Poškus and Poškienè, } 2015 \text { [61]; Rall et al., } \\
2017 \text { [62]; Ramer et al., } 2019 \text { [63]; Robbins, } 2007 \text { [64]; Sewel et al., } 2017 \\
\text { [65]; Teysott, } 1999 \text { [66]; Müller, } 1990 \text { [29]; Trigger and Mulcock, } 2005 \\
\text { [44]; Yang et al., } 2019 \text { [4,67] }\end{array}$ \\
\hline & $\begin{array}{l}\text { Urbanisation and } \\
\text { homogenisation }\end{array}$ & $\begin{array}{l}\text { Antrop, } 2004 \text { [68]; Groffman et al., } 2014 \text { [11]; Ignatieva and Hedblom, } \\
\text { 2018 [1]; Pondichie, } 2012 \text { [69] }\end{array}$ \\
\hline & $\begin{array}{l}\text { Health and well-being } \\
\text { aspects }\end{array}$ & Elgizawy, 2016 [57]; Payne and Bruce, 2019 [70]; Stolz et al., 2018 [71] \\
\hline \multirow[t]{2}{*}{ History of lawns } & History of development & $\begin{array}{c}\text { Ignatieva, } 2017 \text { [22]; Ignatieva, } 2018 \text { [72]; Ignatieva and Hedblom, } \\
\text { 2018 [1]; Fischer et al., } 2013 \text { [38]; Gaynor, } 2017 \text { [73]; Hipple, } 1957 \text { [74]; } \\
\text { Jenkins, } 1994 \text { [59]; Robins, } 2007 \text { [64]; Robinson, } 1991 \text { [75]; Yang et al., } \\
2019 \text { [4,67] }\end{array}$ \\
\hline & Lawn as a site of conflicts & Greenbaum, 2000 [76]; Harari, 2016 [77]; Trudgill et al., 2010 [78] \\
\hline \multirow[t]{3}{*}{ Lawn alternatives } & $\begin{array}{l}\text { Searching for lawn's } \\
\text { alternatives and } \\
\text { sustainable lawn } \\
\text { management }\end{array}$ & $\begin{array}{l}\text { Alumai, } 2008 \text { [79]; Burgin, } 2016 \text { [37]; Chawla et al., } 2018 \text { [80]; } \\
\text { Cumming, } 2018 \text { [6]; Gaynor, } 2017 \text { [73]; Hogue and Pinceti, } 2015 \text { [16]; } \\
\text { Ignatieva et. al., 2008 [23]; Ignatieva, 2010 [81]; Ignatieva and Ahrné, } \\
2013 \text { [82]; Johnson, } 2013 \text { [40]; Pineo and Barton, } 2010 \text { [83]; Schapel et } \\
\text { al., } 2018 \text { [55]; Steinberg, 2006 [84]; Teysott, 1999 [66]; Wasowski and } \\
\text { Wasowski, 2002 [85]; Wasowski and Wasowski, 2004 [86]; Wastian et } \\
\text { al., 2004 [46]; Wilson and Feuch, } 2018 \text { [87]; Zollner, } 2018 \text { [88] }\end{array}$ \\
\hline & Alternative to lawns & $\begin{array}{c}\text { Bormann et al., } 2001 \text { [89]; Daniels, } 1995 \text { [90]; Hitchmough, } 2004 \text { [91]; } \\
\text { Ignatieva, } 2017 \text { [22]; Ignatieva, } 2018 \text { [72]; Ignatieva and Hedblom, } \\
2018 \text { [1]; Robinson, } 1991 \text { [75]; Sprajcar, } 2017 \text { [92] }\end{array}$ \\
\hline & $\begin{array}{l}\text { Artificial lawn related } \\
\text { aspects }\end{array}$ & $\begin{array}{l}\text { Brooks and Francis, } 2019 \text { [93]; Chawla et al., } 2018 \text { [80]; Fleming et al., } \\
2013 \text { [18]; Kaminski, } 2019 \text { [19]; Loveday et al., } 2019 \text { [94] }\end{array}$ \\
\hline Two natures & $\begin{array}{l}\text { Novel and designed } \\
\text { ecosystems }\end{array}$ & Higgs, 2017 [95]; Hobbs et al., 2006 [96]; Kowarik, 2011 [97] \\
\hline
\end{tabular}

\section{Ecosystem Services and Disservices of Urban Lawns}

Lawns are specially designed ecosystems that originated in Europe in Medieval times [22]. We define lawn as a managed, artificially created grass-dominated plant community, designed for fulfilling a range of ecosystem services. This plant community predominantly consists of grass species-cultivars, as well as spontaneously occurring and unwanted herbaceous species known as "lawn weeds" [22,29]. One crucial aspect of lawns is the uniform phenomenon of a turf (sod), which is the upper level of soil that is covered by closely knit grasses and forbs intertwined with their roots or/and stolons, and which are in symbiosis with soil and fauna. Turf, in particular, is responsible for creating the uniform and "durable" surface commonly used by people for recreation and sport.

Lawns provide a full range of ecosystem services such as regulating the water cycle by promoting infiltration, thus facilitating regeneration of ground-water stocks and evapotranspiration [42]. In addition, lawns mitigate the heat-island effect through transpiration and evaporation and provide cooler microclimates [98]. Another important ecosystem service of lawns is habitat provision for some urban fauna species [37]. Lawns also support soil organisms. Since their introduction, the most recognised ecosystem service of lawns has undoubtedly been the cultural aspect, i.e., the creation of the specially designed leisure spaces (Figure 3).

Along with these positive contributions to human life and well-being, there are a number of ecosystem disservices created by urban lawns, such as those presented in Figure 4. According to Shackleton et al. [54], ecosystem disservices are commonly understood as "the ecosystem-generated functions, processes and attributes that result in perceived or actual negative impacts on human well-being". These negative effects arise from ecosystem characteristics that are economically or socially harmful or that endanger health or may even be life-threatening [47-50]. This includes sheltering species such as pathogens and parasites harmful to human health, damaging pests [41] or those that 
attack humans [49]. In the case of lawns, among the most recognisable disservices are dust pollution and loss of aesthetic qualities during hot and dry summers and surface and ground pollution as a result of using herbicides and pesticides. In the following sub-chapters, we discuss ecosystem services and disservices in details. There is a clear pattern related to human activity, economics (availability of resources for management) and environmental factors beyond human control (draughts, heat waves, floods). At some stage, a definite positive ecosystem service can turn into a definite disservice. For instance, one of the main ecosystem services of lawns that they are a place for recreation, however, when there are too many users and heavy trampling, the lawn's surface becomes degraded, uneven and even dangerous for users. Due to the particular significance of cultural aspects of lawns and a number of studies of this particular phenomenon, the cultural services of lawns received additional scrutiny in this paper (Sections 3.1-3.3).

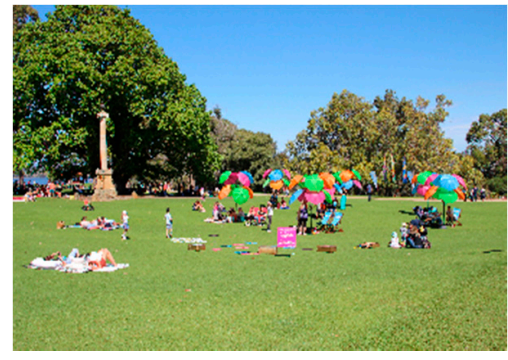

(a)

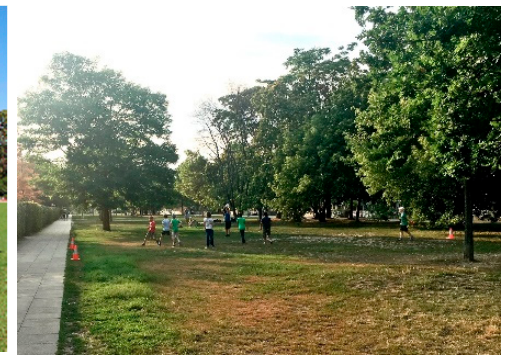

(b)

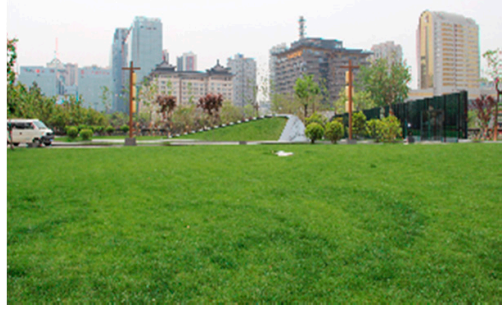

(c)

Figure 3. Lawn as a special leisure space in urban parks worldwide: (a) King's Park in Perth, Australia; (b) Lene-Voigt Park in Leipzig, Germany; (c) one of the public parks in Xian, China. Photos: M. Ignatieva, D. Dushkova.

\begin{tabular}{|c|c|c|}
\hline Ecosystem services provided by lawns & Lawn mediated ecosystem functions & Ecosystem disservices provided by lawns \\
\hline $\begin{array}{l}\text { Cooling/mitigation of heat-island } \\
\text { effect by transpiration and evaporation }\end{array}$ & $\begin{array}{l}\text { 1. Regulating: } \\
\text { 1.1. Air temperature regulation }\end{array}$ & $\begin{array}{l}\text { During dry and hot summers in places with } \\
\text { no watering - dust pollution }\end{array}$ \\
\hline $\begin{array}{l}\text { Carbon sequestration } \\
\text { benefit }\end{array}$ & $\begin{array}{l}\text { Regulating: } \\
\text { 1.2. Carbon sequestration }\end{array}$ & $\begin{array}{l}\text { Can be negated by using fuel mowers and } \\
\text { frequent intensive management }\end{array}$ \\
\hline $\begin{array}{l}\text { Cooling/mitigation of heat-island effect } \\
\text { by transpiration and evaporation }\end{array}$ & $\begin{array}{l}\text { Regulating: } \\
\text { 1.3. Air quality }\end{array}$ & $\begin{array}{l}\text { Greenhouse gas emission and dust through } \\
\text { intensive management (frequent mowing by } \\
\text { fuel operated mowers) }\end{array}$ \\
\hline $\begin{array}{l}\text { Regulation of the water cycle } \\
\text { (infiltration, regeneration of ground- } \\
\text { water stocks and evapotranspiration) }\end{array}$ & $\begin{array}{l}\text { Regulating: } \\
\text { 1.4. Water quality }\end{array}$ & $\begin{array}{l}\text { Overuse of water; spreading of herbicides } \\
\text { and fertilizers - surface and groundwater } \\
\text { pollution; pollutions by microplastics from } \\
\text { artificial lawns }\end{array}$ \\
\hline $\begin{array}{l}\text { Irrigated lawns provide habitat for some } \\
\text { fauna species (some flowering } \\
\text { herbaceous species in "old" lawns } \\
\text { available for pollinations, e.g. bees; } \\
\text { forage for some birds and mammals) }\end{array}$ & $\begin{array}{l}\text { 2. Supporting: biodiversity } \\
\text { support and habitat provision }\end{array}$ & $\begin{array}{l}\text { Loss of native habitats, only some } \\
\text { specialised 'urban specialist' species } \\
\text { benefit. Invasiveness of some grass species }\end{array}$ \\
\hline $\begin{array}{l}\text { Enhancing private property value, symbol } \\
\text { of prestige and power }\end{array}$ & $\begin{array}{l}\text { 3. Cultural: } \\
\text { 3.1. Aesthetic }\end{array}$ & $\begin{array}{l}\text { Ecological homogenlsation, high resource } \\
\text { input, unification of design }\end{array}$ \\
\hline $\begin{array}{l}\text { Recreational activities } \\
\text { (including sport) }\end{array}$ & $\begin{array}{l}\text { 3. Cultural: } \\
\text { 3.2. Recreation }\end{array}$ & $\begin{array}{l}\text { Degradation of ground surface because of } \\
\text { overuse (trampling); Dying, unattractive } \\
\text { brown surfaces in the absence of irrigation }\end{array}$ \\
\hline
\end{tabular}

Figure 4. Ecosystem services and disservices provided by lawns.

The majority of research that analyses lawn ecosystem services (directly or indirectly for example in the research of wildlife in private urban gardens) is based on case studies from the temperate latitudes of the northern hemisphere, namely from Europe (40\% of publications) and the US-60 $\%[3,5,16,22,24,29,42,46,59,65,72,86]$. From sources related to the study of lawns (not including alternative lawns), only three were from China directly connected to ecological and cultural aspects of Chinese 
lawns $[4,67,99]$. Australia had the most publications related to cultural aspects (history of lawns and their connection to colonial culture [73], positive outcomes of lawns for hot and dry urban environment and how to develop sustainable management of lawns (waterwise irrigation, relevant soil preparation and species selection). There are number of publications on Australian urban private garden wildlife where lawns are mentioned as a new habitat for exotic and native wildlife species [44]. The first direct ecological research on lawns (the biodiversity of lawns) in New Zealand resulted in several publications in the late 2000s $[30,81]$.

\subsection{Cultural and Aesthetic Services of Lawns: Historical Roots}

From a societal and cultural perspective, lawns are one of the most important and frequently used types of urban green infrastructure. From the very introduction of lawns into Europe as a crucial garden element during the Middle Ages, their most advertised value was primarily cultural and aesthetic function. In actual fact, lawns were introduced purely as a decorative element for human enjoyment, and not associated with any direct economic value. Subsequently, they have been rapidly developed in periods of political stability and technological progress in Western Europe [22].

Since their development, lawns have required both space (land) and labour to provide constant management (especially in the early stages of their use in the 16th and 17th centuries). One important purpose of lawns was intangible-as symbols of power and prosperity. This important symbolism of power, order and control over nature can be found in all countries across the centuries-from French and English gardens designed for the aristocracy, to important contemporary public buildings and private residences of high-income urbanites around the globe [76,77] (Figure 5). From the 18th century onwards, lawns were designed according to the ideas of the picturesque movement (end of the 18th century to the beginning of the 19th century). At that particular time, smooth and gently rolling turf surfaces were revered as the most "beautiful" landscapes [76]. European countries and colonies designed numerous park-like landscapes according to this standard of English "beauty".

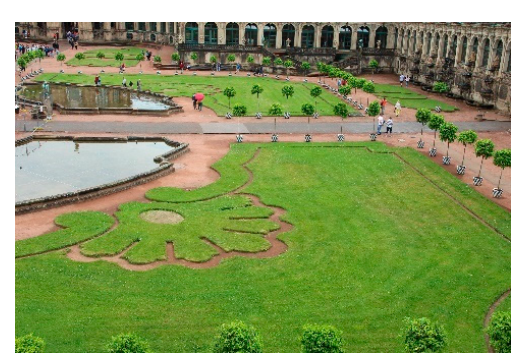

(a)

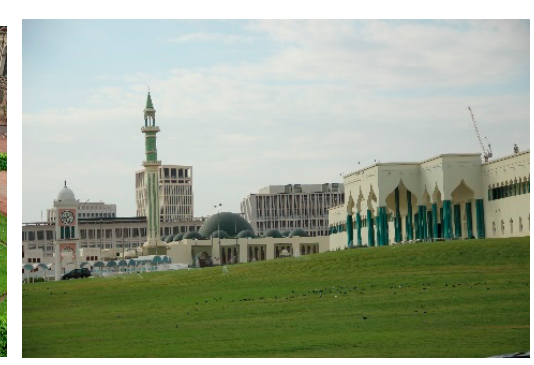

(b)

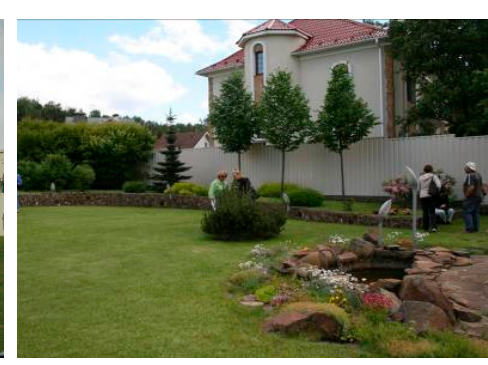

(c)

Figure 5. Lawns as symbols of beauty, power and prosperity: (a) Lawns are a dominant feature of decorative parterre in the formal (French style) garden of Zwinger Palace, Dresden, Germany; (b) Lawn in front of a mosque in Doha, Qatar; (c) Manicured lawn in a private villa, suburb of Moscow, Russia. Photos: M. Ignatieva.

The English garden with its admiration of the countryside and pastoral landscapes (and using both pastures and lawns in their vocabulary) became a kind of "buffer" between "wildness of nature and the stiffness of art" [74], (p. 241). The majority of English gardening practitioners and scholars of the picturesque movement agreed that the garden area next to the main house should be covered by cut lawns, otherwise it would demonstrate a step away from civilisation [75].

It is very important to note, that English parks used native grassland species for their lawns that were also widely used in pastures. The success of these species on lawn surfaces was due to the mild English climate, high rainfall and appropriate soils.

From the very beginning of the public parks movement in the mid-19th century lawns have served the function of public recreation $[59,64,66,75,78,84]$. Public parks are based on the model of the British pastoral landscape aesthetic where green grass areas played the essential role. Another highly 
recognised recreational benefit of lawns is their provision of surfaces for sports like football, cricket and golf. All these games are rooted in the British Isles.

With technological progress and the invention of mowers for the common man, lawns became more widespread in private suburban gardens in the UK, Australia, New Zealand and to a significant extent in the USA (Figure 6). The majority of existing literature on colonial lawns is dedicated to researching the social perception and analysis of the American attachment to perfect home lawns [59,66,79]. American authors believed that, despite the lawn being primarily an English feature, the US "front lawn" became the most powerful sociological manifestation and an obligatory element of the American lifestyle. Lawns in America stand for personal respect and being a good citizen, and are associated with public health and even safety. For example, in short cut lawns dangerous creatures such as snakes or ticks would have no chance to appear [66]. Today, the United States is one of the largest producers and consumers of turf, and turf represents the largest irrigated non-food crop in the country $[24,79,80,83]$.

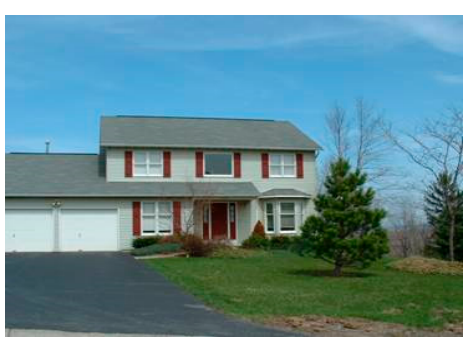

(a)

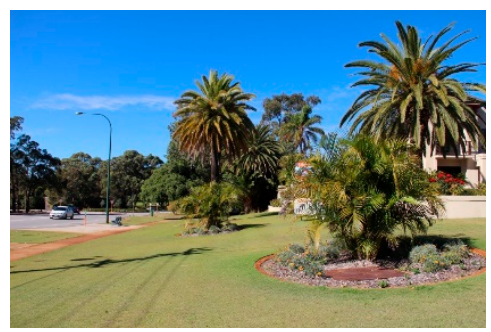

(b)

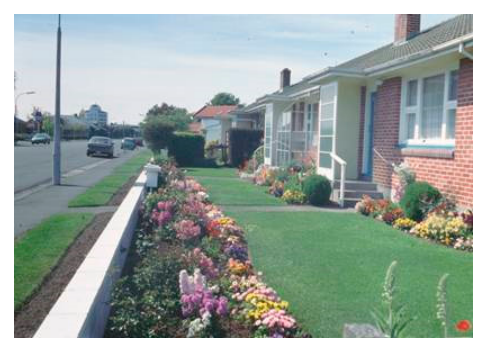

(c)

Figure 6. Lawns in private gardens: (a) USA (Syracuse, NY), (b) Australia (Perth) and (c) New Zealand (Christchurch). Lawns are obligatory elements of suburbia. Photos: M. Ignatieva.

\subsection{Cultural Services of Colonial Lawns: Australia and New Zealand}

Colonial lawns were introduced to Australia and New Zealand as the important aesthetic heritage of England, together with other garden, planning and architectural archetypes. In New Zealand, lawns became part of the newly established public parks, private estates, and suburban gardens and they used the picturesque-gardenesque aesthetics. European grasses were well adapted to New Zealand's temperate climate. Christchurch, for example, is called "the most English city outside of England" [100].

In Australia, establishing turf was more difficult due to the heat, frequent droughts and unsuitable soils for European turf species. In other words, these were unusual and hostile environmental conditions for lawns. Whereas most lawn grasses in Europe have their origins in the native or secondary grasslands of that region, in the southern hemisphere, all suitable turf species were non-native plants. It was therefore a long and painful process to find appropriate non-native species and lawn management regimes for lawns in the southern hemisphere. Particularly in the dry climates of Western and South Australia, the turf industry faced many challenges. Grasses in poor soils would not grow without constant irrigation and fertiliser application.

Concerning the early days of settlers in Perth, Gaynor [73] (p. 4) states that "grass and other garden plants were allies in a war against the heat and dirt that perpetually invaded settlers' homes and their dreams of creating a 'civilised' city, and the alliance was forged and maintained with water". For early Australian settlers, lawns, as part of a cultivated and irrigated garden, were a powerful symbol of the supposed superiority of European civilisation in contrast to the Indigenous (Aboriginal) wilderness. These lawnscapes were in opposition to the wildness of "the bush" and the bush referred to the" wild" places, the shrublands, forests, mountains, deserts and sometimes even the rural countryside [101].

To the first settlers in Australia and New Zealand, native plants were unattractive and appeared "alienating". Plants were never as green as those in England. A similar attitude towards the surrounding "messy" wildness has persisted in the modern landscape. The colonial symbolism of the well-kept private garden has not changed in the 20th and the 21st century. A neat garden indicates neighbourhood status and high property values. This separation of urban landscapes where lawn and exotic decorative 
plants are delineated from native bushland is the foundation for the existence of two different "natures" in Australian and New Zealand cities (Part 4).

\subsection{Cultural Services of Lawns: Recreation}

From an urban sociological standpoint, there are various ways that lawns are utilised. One of the main values of conventional lawns is the space they provide for social activities such as picnicking, resting, sunbathing, walking dogs, games and sports [102]. Another important function, which was connected to the 19th century gardenesque style, was the use of lawns as aesthetic backgrounds for architecture and art elements [22].

Recent studies from Europe and USA have revealed that people's love of lawns is connected to the integral role lawns play in the everyday landscape $[1,22,60-63,71,72]$. Short cut lawnscapes are associated with improved quality of life and personal safety. Lawns, with their openness and good visibility, are opposed to dense shrubs and woodlands which can hide dangerous people. In arid developing countries where water shortage is paramount, lawns are nevertheless used to green workplaces and are seen as primary vehicles for enhancing the quality of human life [57].

In Scandinavian countries, due to the cold climate and subsequent lifestyles, lawns can only be used from late May to October [22]. In parts of Central and Western Europe with milder climates, lawns can be used for longer periods of time. In Europe, due to the changing climate and with warmer winters and extended summer temperatures, lawns are used throughout the whole year. There is evidence that some German city lawns in urban parks are being used from February to November, which is far longer than in previous decades. This prolongation of the growing season has led to lawns being overused and not being afforded necessary recovery periods.

In China, due to the very recent introduction of lawns to urban public spaces and to certain specific socio-cultural practices (overuse of green spaces), lawns are not accessible for general recreation but only play a decorative (aesthetic) role in urban landscapes [4]. In warm, humid or arid climate countries, lawns are used all year round, however, their condition is dependent on irrigation which raises concerns of overuse of water, particularly in arid cities.

These days, lawns are used for a broad range of activities—for quiet recreation (reading, talking and walking) to sports, plays, parties, barbecues and picnics (Figure 7). Due to the "mediteranianisation" of European lifestyles, people would like to spend more time outside [62].

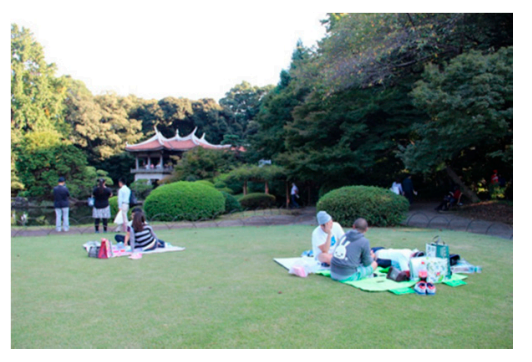

(a)

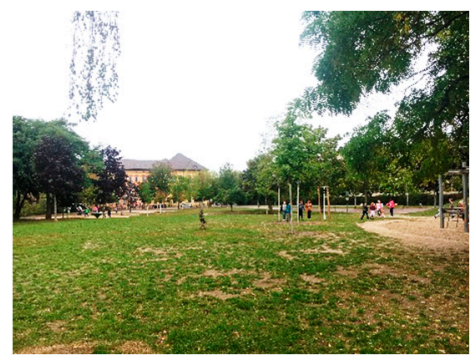

(b)

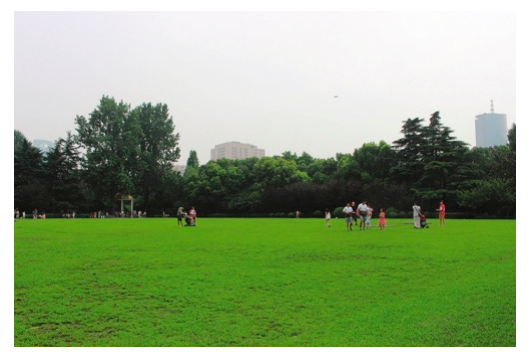

(c)

Figure 7. Lawns provide the main arena of human activities in cities today: (a) Park in Tokyo (Japan), (b) Rabet Park in Leipzig (Germany), (c) Gujiazhai Park in Shanghai (China). Photos: M. Ignatieva, D. Dushkova.

Today, the lawn is idealised as a universal cultural norm and is considered the most "beautiful" aesthetic function of urban landscapes, which in turn, helps to create positive human psychological and physical health $[22,78,103]$.

In recent years, the main cultural and aesthetic disservices of lawn are caused by the increasing recreational pressure put on publicly accessible parks resulting in large compacted, trampled areas. There are simply more people who want to use lawns. This leads to degradation of the lawn surface, 
to a greater input of resources (watering, aeration and fertilisers) and to constant repairs of damaged areas. One of the examples is Görlitzer Park in Berlin which is widely used by local people (parties and festivals) and by tourists. Another example is public parks in Leipzig where recreational pressure significantly increased due to the growing population (Figure 8a). Across Europe, in many cities that have become the destination of youth immigration, park lawns are especially in demand and under pressure [104,105].

In Europe and some countries where watering is restricted or prohibited during dry summers, lawns are turning brown and becoming a significant source of dust [69] (Figure 8).

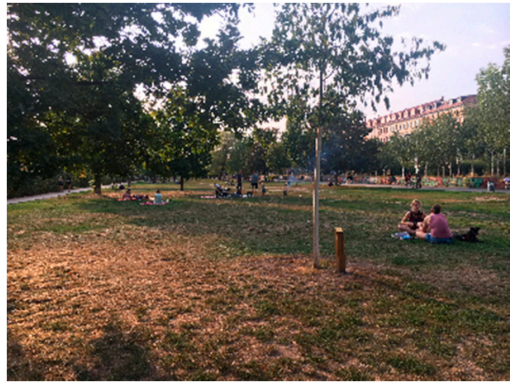

(a)

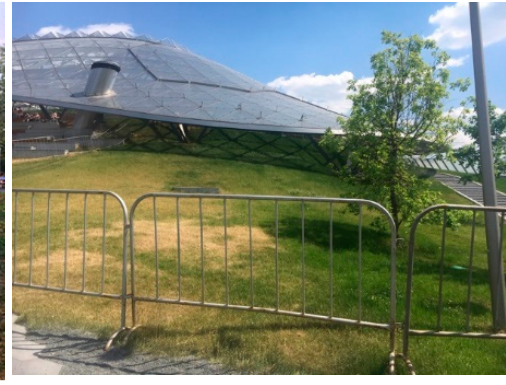

(b)

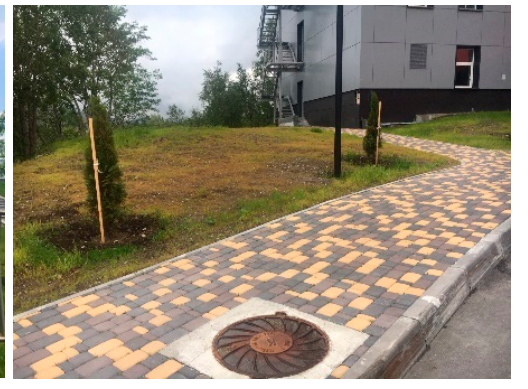

(c)

Figure 8. Degradation of lawns from overuse (trampling) and drought. Lawns were established on former post-industrial site (a) or wasteland (c): (a) Lene-Voigt Park, Leipzig (Germany), (b) Zaryadye Park, Moscow (Russia), (c) public green space near a hospital in Kirovsk, Russia. Photos: D. Dushkova.

In shrinking European post-industrial cities, urban lawns are also frequently used after the demolition of housing or industrial structures. This is a fast method for reviving open space and making it accessible for recreation $[106,107]$. In such areas, the soil can often be very thin and grass species struggle to survive. In contrast, planted trees and shrubs in such areas receive more attention and better maintained. This is particularly acute in urban parks that are created on former brownfields. Those parks suffer much more during hot and dry summers. Thus, lawns become almost unusable and cannot fulfil their recreational function.

\subsection{Mitigation of the Heat Island Effect, Carbon Sequestration and Regulation of the Water Cycle}

The cooling effect of lawns is well recognised and is always used as an argument for the importance of grass-covered areas (part of green infrastructure) versus hard urban surfaces (grey infrastructure not covered by vegetation). The cooling capacity of lawns is directly related to the evapotranspiration process and very much depends on water availability. In temperate climates, lawns have shown their capacity to decrease the temperature peaks of hot summer days by approximately $1{ }^{\circ} \mathrm{C}$ [42].

Proper irrigation regime enhanced the cooling effect of grasses [33]. Irrigated turf has become an important factor for the mitigation of the urban heat island effect in hot arid climates, such as Australian cities [98]. For example, in Adelaide, where a warming trend is occurring as a result of climate change, by 2070 the maximum temperatures during January and February are expected to exceed $45^{\circ} \mathrm{C}$, which is higher than the average maximum temperatures between 1980 and 1999 of $43^{\circ} \mathrm{C}$ and between 2000 and 2012 of $44^{\circ} \mathrm{C}$. Heat mapping of urban areas as well as high resolution thermal infrared imagery of $285 \mathrm{~km}^{2}$ region of Adelaide's southern suburbs showed that the coolest sites were golf courses, water bodies, dense woody vegetation and irrigated turf, while the hottest areas were generally comprised of buildings, dry agricultural fields, dry/dead grass and vegetation, exposed soil and unshaded hard surfaces [108]. Research into surface temperatures of hard and soft urban landscape elements in Perth, Western Australia, found that areas with grey pavers were the hottest, whilst areas with ground-cover plants were the coolest. In the evenings, grey pavers remained the hottest, whilst decking, soil, and turf grass were the coolest [94]. 
Another recognised ecosystem service of lawn is carbon sequestration. In temperate zones of Europe and the USA, carbon sequestration has been positively associated with carbon accumulating in the soil [42]. However, other recent studies of the northern hemisphere temperate zones have shown that the positive effects of soil carbon sequestration in intensively managed lawns can be negated by greenhouse gas emissions generated by the routine management operations of mowing, fertiliser application and irrigation [22]. In the Newcastle region in Australia domestic lawn-mowers contributed $5.2 \%$ and $11.6 \%$ of carbon monoxide (CO) and non-methane hydrocarbons emissions (NMHC), respectively [52].

Park and garden soils in western and eastern European countries have experienced several centuries of enriched soil fertility and, accordingly, increased humus amount in soils. In cities where lawns are created on sandy soils, such as Perth, these soils require a lot of input from the outset to grow turf grasses because of their limited water and nutrient capacity. Recent research has shown that "excess nitrogen and phosphorus leaching beneath urban lawns on sandy soils in metropolitan Perth may pose a serious threat not only to the quality of the underlying groundwater but also to many surface-water bodies" [56] (p. 1).

Northern hemisphere case studies from USA and Europe have outlined the importance of turf for reduction of water runoff and increased water infiltration, with resulting in flooding problems and increase in water recharging [42]. However, the data is limited and, in most scenarios, it is based on cases from temperate climates that are not directly obtained from researching turf grass urban ecosystems. For lawns in arid and semi-arid regions, water-related issues are typically considered disservices rather than services. To maintain living and green turf grass, substantial irrigation is required. Studies from arid zones of the United States have revealed that lawn used up to $75 \%$ of the total annual household water consumption [24]. In southern hemisphere cities, for example in Perth, gardens accounted for over half of the city's water use in 1970's. Perth's total water usage, accounting for scheme water usage, regulated bore water abstraction and estimated private garden bore usage between 2017 and 2018 was 629,390 mega litres. Approximately 258,403 mega litres (41\%) of this amount was used for the irrigation of lawns and gardens, of which $79 \%$ was drawn from groundwater [109].

Without irrigation in such dry conditions, lawns are becoming dry, brown, dusty and unappealing to people. In Germany, Sweden and England, watering is not allowed for public green areas during hot summers, thus lawns and street trees are rapidly degrading. Some grasses recover after late summer rainfalls, however, the damage is visible and turf surfaces often need to be repaired. In many Australian cities (for example in Melbourne and Sydney) and semi-arid states of USA (in California and Arizona) there are a strict water conservation efforts and restriction policies against using water for lawn irrigation [16]. In Australian cities, only some species of turf grasses are capable of reviving after summer droughts. Others just die and a whole new lawn needs to be reinstalled. As they offer a quick solution to keeping an urban yard or playground "clean" and "green", the synthetic lawn industry has boomed all over the globe. (Figure 9). However, ecological and sociological research into such substitute for nature is limited. There is concern that material used for plastic non-living lawn reduces urban habitat, suppresses soil fauna, pollutes runoff via plastic and synthetic particles and other unknown impacts on the environment $[18,19,93,110]$. Loveday et al. [94] revealed that artificial turf grass can be particularly hot, often more than $30^{\circ} \mathrm{C}$ above turf grass.

In many cities where herbicides and pesticides are used to keep lawn uniform and tidy, there are concerns of contamination of groundwater and runoff water. For example, in 2012, US houses applied up to 57.6 million kilograms (12.7 million pounds) of pesticide to lawns [111]. The most recent and widely discussed example is Roundup ${ }^{\mathrm{TM}}$ —one of the most widely used herbicides on the planet. The International Agency for Research on Cancer (IARC), classified glyphosate (the active ingredient in Roundup ${ }^{\mathrm{TM}}$ ) as "probably carcinogenic to humans" [112]. 


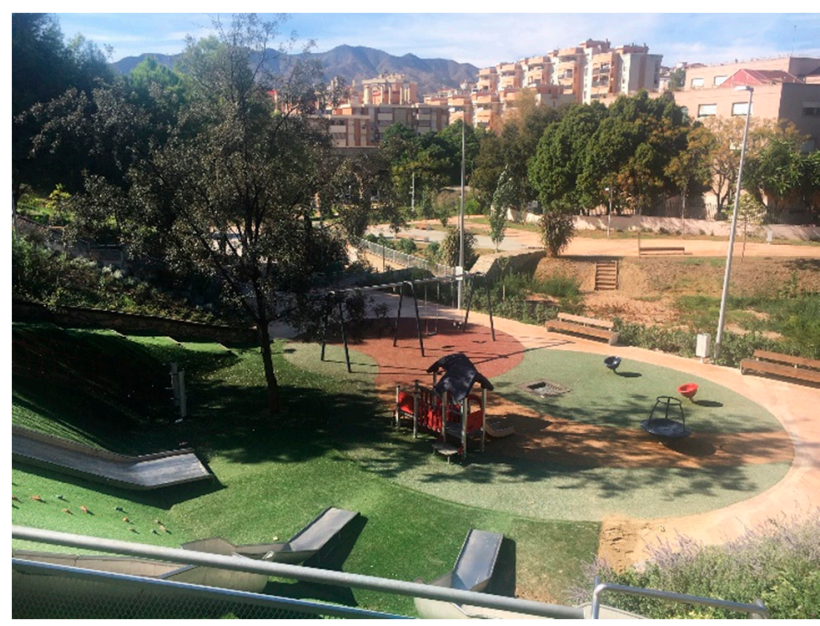

(a)

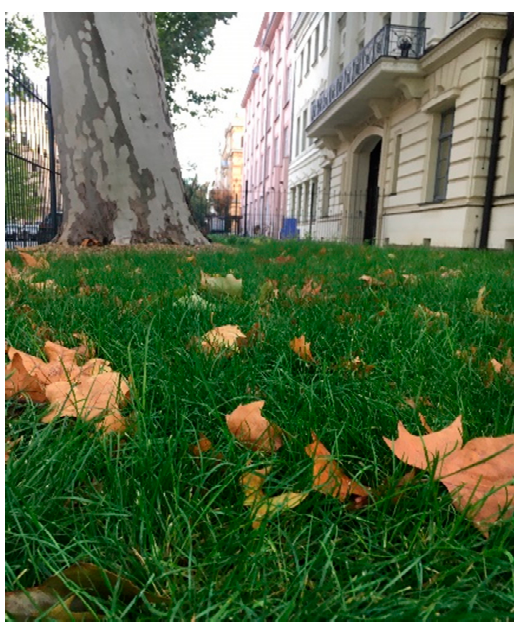

(b)

Figure 9. Synthetic (plastic) lawns in a playground in Malaga (Spain) (a), and front yard of a residential building in Leipzig (Germany) (b). Photos: D. Dushkova.

\subsection{Habitat (Biotope) Provision}

Since lawns consist of sod, a combination of grass roots and soil, they support particular type of wildlife, for example, insects (ants and some species of beetles), nematodes, earthworms and spiders. Older lawns in the northern hemisphere temperate climate usually include some broadleaf herbaceous species (Trifolium repens, Potentilla anserina, Prunella vulgaris), that are capable of adapting to the mowing height. The life habits of these plants adapt to a frequent mowing and allowed them to go through their life cycle and produce flowers, thus attracting pollinators such as bees and bumblebees [22].

Some domestic lawns and moderately visited park lawns in Europe are attractive to small herbivorous animals such as rabbits and hares. Lengthening the mowing interval and creating a timed schedule for mowing to allow for the flowering of broadleaf herbaceous species such as clover, would increase the diversity of plants in the lawn and pollination and grazing opportunities for wildlife.

In the southern hemisphere, especially in Australia and New Zealand, the aim of maintenance of domestic and public lawns is to achieve a homogenous green carpet-like appearance (Figure 10).

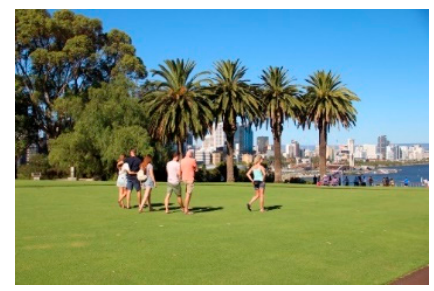

(a)

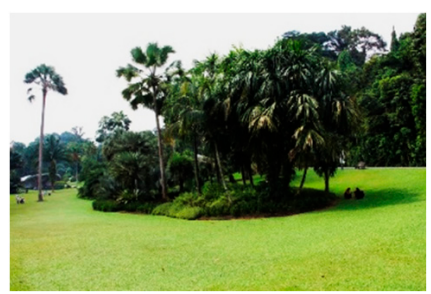

(b)

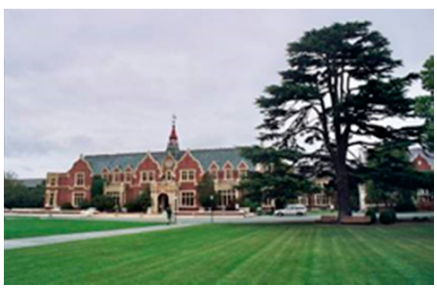

(c)

Figure 10. Ecological homogenization of urban environment in (a) Australia (Perth), (b) Singapore (Singapore Botanic Garden) and (c) New Zealand (Lincoln University Campus). Photos: M. Ignatieva.

Compared to European and USA temperate zones, Australian and New Zealand lawns consist of far fewer native plants, which are unable to grow amongst the dense exotic grasses due to their very different life strategies. Since native plant communities are either destroyed or replaced by irrigated lawns, native fauna has to adapt and use lawn grasses as a food source. For example, the native bird, little corella (Cacatua sanguinea) is regularly seen browsing on irrigated lawns (in parks and sports fields) in Canberra, Sydney and Brisbane. The Australian magpie, ibis and wagtail birds are also a very common forager of Australian urban lawns [44]. Among non-avian taxon who prefers urban lawns in the Pacific coast of Australia is the can toad (Rhinella marinus) introduced from South America and 
becoming a problem. Can Toad's toxin kill household pets and any native species that will attempt to prey on them [37]. Many invasive urban bird species also feed on urban turf grasses. In Australia's increasingly dry environment, especially over the last decade, irrigated urban lawns have become desirable food sources for large marsupials such as kangaroos (Figure 11) [113]. The Eastern and Western grey kangaroo often forages on golf course turfs and urban lawns. For local turf producers and golf courses greenskeepers, kangaroos are seen as a nuisance. They can also ruin fences and cause hazards on the roads. In Canberra, urban lawns are one of the main habitats for the rabbit-an introduced animal that is now considered a pest in Australia. In these cases, the positive ecosystem service of "providing wildlife habitat" has turned to a disservice.
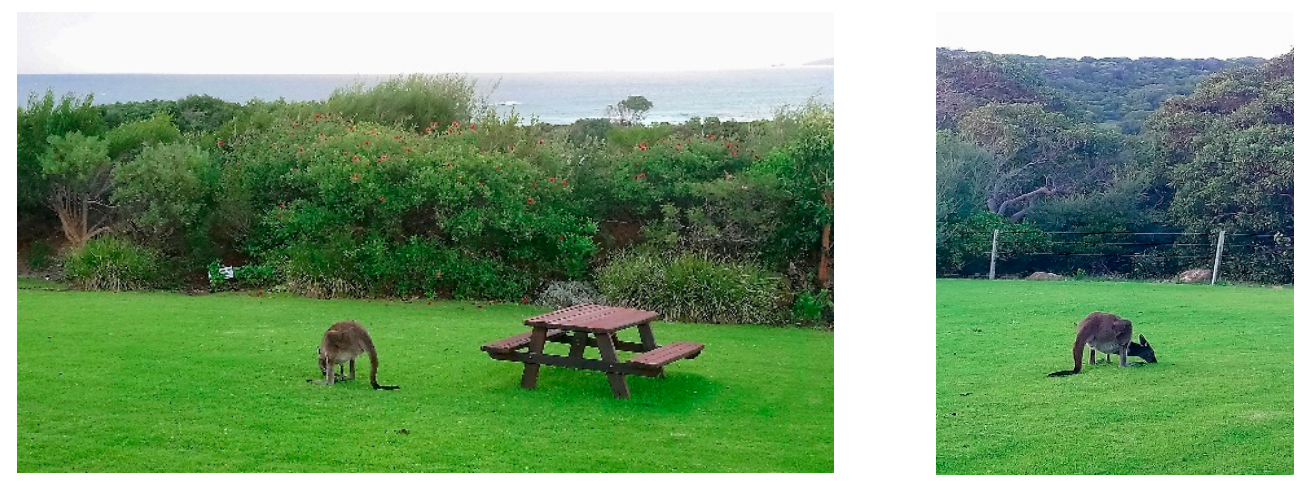

Figure 11. Urban lawns have become a desirable food source for Kangaroos in Western Australia. Photos: M. Ignatieva.

Australian lawns also provide habitat for other harmful pests such as the stinging nematode (Ibipora lolii). Infestations of this accidentally introduced parasitic nematode (possibly originating in South America or the Caribbean) have resulted in grass with shallow root systems, sparse turf cover and bare patches in many sports fields and recreational areas [43].

Over the last decade, the most noticeable and widely discussed ecosystem disservice of lawns is aesthetic uniformity resulting in the ecological homogenisation of urban areas, with lawn plant communities becoming similar in composition and structure across numerous biogeographical zones [1]. The demand for these monotonous green surfaces can only be met by using monocultures of one or two species. In temperate climates, four European species, Poa pratensis, Festuca rubra, Lolium perenne and Agrostis spp. are widely grown in turf grass nurseries. In warm climate countries, the most common are Cyonodon dactylon (native to Africa), Stenotaphrum secundatum (originally from Central and South America), Paspalum vaginatum (from the Americas), Pennisetum clandestinum (East Africa) and Zoysia japonica (from southeast Asia and Indonesia). The main method for maintaining the homogeneous composition is establishing lawns by seeding or by vegetative planting and eliminating any other species (weeds) by applying herbicides and frequent mowing.

Another ecosystem disservice of lawns, especially in non-European countries, is the invasive capability of some lawn grass species, with many spreading into native biomes. One classic example is the most famous lawn species, Cyonodon dactylon. This species was listed by the Global Compendium of Weeds as one of the top 12 cited invasive weeds in the world [114]. Increasing the biodiversity of lawns can be achieved by leaving some native or spontaneously appearing broadleaf flowering plants to attract pollinating insects. However, this is controversial in light of the attitudes to the conventional lawn-that it should be a highly manicured and controlled plant community where other plants are undesirable.

\section{Two Natures}

Lawnscapes dominate urban landscapes and people perceive urban "nature" through the prism of lawns $[22,59,64,66,78,84]$. When a person steps on the grass beside of a road or outside a building, it is 
often their only daily contact with nature. In cities with no or very limited access to wild vegetation or other pristine nature, urban dwellers have an even stronger connection and association with turf grass as nature. Turf grasses together with other "natural features" consisting of living organisms such as trees, flowerbeds, shrubberies and water bodies form this vision of nature [57].

Historically, European preferences for grassy surfaces were transferred and adopted in other countries and communities. For many centuries, European green areas consisted of native species and included natural or semi-natural vegetation. By the 19th century, the English vision of urban green spaces dominated the USA, Australia, New Zealand and European colonies [81]. European settlers literally transferred their values of turf grasses to their colonies and created a new version of urban nature. It was a new "civilised" European nature based on exotic species that were opposed to wild nature. Mowed lawn was often used as a demarcated line between these two natures. We argue that in Europe there is only one urban nature and in Australia and New Zealand there are two urban natures.

\subsection{European Urban Nature}

European researchers in their post-World War II studies of urban ecosystems saw urban nature as a heterogeneous and complex phenomenon. Their vision of urban nature included all types of urban biotopes-remnants of "pristine" forest, semi-natural modified groves, designed urban parks, small community gardens, abandoned wastelands or ditches or cracks in walls or pavements $[31,81,82]$. Most Western and Central European landscapes were modified during the long history of human settlements [68]. Some introduced decorative and crop species that had escaped from cultivation and, with time, became integral parts of urban ecosystems. Studies of European urban ecology consider the naturalisation stages of urban flora and vegetation [31]. The degree of naturalisation and invasiveness in Northern, Central, Eastern and Western Europe is still not as severe as urban environments in the New World. For example, in Central Europe the original flora consisted of 2,400 vascular plants. Since 4000 BC. more than 12,000 taxa have been introduced and only $279(2.3 \%)$ have naturalised in natural plant communities [51]. In New Zealand, flora comprises about 2500 indigenous plants $(80 \%$ of them are endemic). However, since European arrived in the 1840s, over 25,000 exotic plants have been introduced and one tenth of them have already become naturalised, with four more entering the wild each year [81,115].

In Europe, urban nature is still dominated by native flora including urban lawns. Due to the ecology of European native biomes which have undergone numerous disturbances, there are effective recovery mechanisms for disturbed ecosystems. A large number of native pioneer species in the soil seedbank allows urban biotopes to quickly regenerate. The typology of European lawns and their composition and structure is regulated by management and, first of all, by the frequency of mowing. For example, in Sweden there are conventional lawns that are frequently mown and meadow-like lawns (high grass and meadows), that are cut one to two times per year. High grass areas have a greater potential for biodiversity when properly maintained (collecting clippings after cutting to restrict soil fertility) and with a proper mowing schedule (at the right time of the season) [22].

The majority of urban ecology research in North America is based on temperate cities and also regard "urban nature" as an entity that is not separated from wild nature and manmade (designed) nature. In the US, the urban-rural gradient approach is the most popular method of studying urban ecosystems. American cities have the dominant urban planning model: central-business, district-sprawl and suburbia-rural ecosystems [116]. North American urban ecologists have also focused more on remnant indigenous vegetation for example urban forest [117]. However, the USA has quite substantial input on socio-cultural research of urban lawns [64,118].

\subsection{Australian Urban Nature}

In Australia and New Zealand, "nature" typically refers to natural indigenous ecosystems. While Europe has a long tradition from the 19th century of studying urban flora and vegetation with the most advanced classification of plant naturalisation, urban vegetation and urban biotope mapping, 
Australian urban ecology is much younger. Urbanisation patterns were different from Europe and urban development took place in relatively intact native vegetation. Many high-quality remnants of native woodlands, scrublands, grasslands or wetlands survived and could be found scattered through cities and its suburbs [27]. Some of these valuable patches were severely transformed during urbanisation, but some still contain a large proportion of their original vegetation. That is why research of flora and wildlife in urban remnants of indigenous vegetation (forests, woodlands, grasslands, rivers, creeks and wetlands) and principles of their protection and restoration or study of native wildlife species in urban areas are prioritized among Australian urban ecologists $[27,28,32]$. For Australians, "nature" equates to "the bush". This is a very Australian word for wilderness used by the general public and by governmental and public organisations (https://www.bushlandperth.org.au/bush-forever/).

European and North American ecologists introduced and widely used terms such as "urban ecosystems", "urban plant communities", "urban biotopes", "urban habitats". These terms all include urban plants and their assemblages without divisions such as "cultivated", "spontaneously natural" or "natural". In comparison, Australian ecologists use the concept of "novel ecosystems", meaning ecosystems that differ in composition and/or function from present and past historical (meaning original native) systems [96]. Originally, the term "novel ecosystems" was introduced by USA ecologists Chapin and Starfield [119] to recognise "the response of the boreal forest to current and anticipated climatic changes".

The primary goal of accepting and reinterpreting the concept of novel ecosystems by Australian ecologists is to understand invasive species behaviour in native remnants and provide mechanisms for saving and restoring native vegetation. Australia's rapid urbanisation and use of European landscape models has resulted in a dramatic loss of unique and fragile native ecosystems, which existed for thousands of years in isolation with relatively minor human disturbance. Invasiveness in Australian ecosystems is severe, with many introduced decorative and crop species and associated weeds escaping from cultivation into the wild environment [28].

Recently the new term "designed or engineered ecosystems" has complemented "novel ecosystems". Designed ecosystems are described as "requiring intensive interventions to create them and ongoing management to sustain them" [95]. Novel ecosystem as a term is now recognised by European and USA urban ecologists $[97,120]$ and used to explain the character of biodiversity, its level of "naturalness" and capacity for urban biodiversity conservation and protection [121]. Ingo Kowarik [97] has even suggested the concept of "four natures": 1 nature-pristine (forest, wetlands); 2 nature-agricultural (grasslands, fields); 3 nature-horticultural (parks, gardens); and 4 nature-urban-industrial, vacant lots, industrial sites and transport corridors. This typology of urban nature is also reflected in the European understanding of urban landscapes.

Study and practical application of Australian urban ecology in landscape design typically deal with human modification of "wild" or "natural" systems within urban and agricultural lands and uses this knowledge as a tool for the conservation of "native" nature. As for the other "nature" that dominates urban areas, there are still quite a few gaps in urban ecological research especially at the urban biotope level, such as research of lawns (except some historical history literature), public parks or wastelands and abandoned industrial areas. We suggest this urban man-made nature be called "designed and managed" nature (Table 2). Dominated by introduced exotic tropical and subtropical species, lawns and gardens in the hot and dry Australian climate are completely dependent on irrigation, supplementary nutrients, and management. "Designed and managed" nature in Australian cities is based on global landscape design patterns and similar exotic plant material available in nurseries. There is a sharp boundary between "wild" nature and the "designed" urban nature under total human control.

Residents of Australian cities share similar attitudes to the US where lawns in suburban private gardens form a unique middle ground between nature and the built environment [76]. Actually, the majority of urban ecology research of lawns in Australia concerns wildlife in urban private gardens in suburbia. There is a lack of Australian ecological research into "pure" designed and managed nature". 
A better understanding of the structure, composition, flow, succession, resilience, and resistance of urban ecological systems could help bridge the chasm between "designed nature" and "native nature".

In New Zealand cities, which as in Australia, originated as colonial settlements, some ecological research of suburban gardens and urban lawns has been conducted which outlines an important strategy and the potential to return indigenous vegetation into the urbanised environment, thus creating more harmony between "wild" and "designed" nature [23,30,122].

Table 2. Vision of Two Natures.

\begin{tabular}{|c|c|}
\hline Europe & Australia and New Zealand \\
\hline $\begin{array}{c}\text { Urban nature: no separation of native and } \\
\text { non-native components }\end{array}$ & Urban nature means native ecosystems \\
\hline $\begin{array}{l}\text { Urban biodiversity: all components including } \\
\text { remnants of native vegetation (if any), semi-natural, } \\
\text { spontaneously appearing and planted exotic } \\
\text { plant species }\end{array}$ & $\begin{array}{l}\text { Separation of man-made (designed) nature from } \\
\text { native ecosystems (native nature). New Zealand even } \\
\text { introduced a separate term: native biodiversity }\end{array}$ \\
\hline Small percentage of naturalised and invasive species & $\begin{array}{l}\text { Large percentage of invasive and naturalised species } \\
\text { as well as introduced species }\end{array}$ \\
\hline $\begin{array}{l}\text { Europe is the birthplace of the urban nature vision } \\
\text { (landscape architecture styles) }\end{array}$ & $\begin{array}{l}\text { Receiver of European nature vision: "beautiful" green } \\
\text { nature }\end{array}$ \\
\hline More relaxed attitude towards native/exotic approach & $\begin{array}{l}\text { Urban green infrastructure, connectivity of green } \\
\text { corridors, water sensitive design, protection means } \\
\text { conservation, restoration and connectivity of } \\
\text { remnants of native vegetation }\end{array}$ \\
\hline Europe as the "cradle" of urban ecology science & $\begin{array}{l}\text { Very few studies of "designed nature" lawns, } \\
\text { private gardens, post-industrial zones, wastelands, } \\
\text { road vegetation, etc., and their ecosystem services } \\
\text { and potential for sustainable design principles }\end{array}$ \\
\hline $\begin{array}{l}\text { Elaborated methodology of urban ecology research } \\
\text { (flora, vegetation and their related urban ecology } \\
\text { aspects, social perceptions), including ecosystem } \\
\text { service flows of benefits }\end{array}$ & $\begin{array}{l}\text { Very little research into urban soil characteristics, } \\
\text { ecosystem services provision, trample resistance and } \\
\text { stability, social acceptance and preferences and } \\
\text { constraints among different users }\end{array}$ \\
\hline
\end{tabular}

\section{Nature-based Solutions-Existing Alternatives to Lawns}

Our understanding of the nature-based solutions concept is that it hinges on three main criteria: "actions and solutions to societal challenges" (where landscape design and planning of lawns can help to achieve sustainable solutions); inspiration from nature (inspiration for lawns in local native ecosystems or in self sustained urban plant communities); provision of environmental, social and economic benefits for people $[20,21,123,124]$. There are several types of alternatives to lawns in Europe, USA, New Zealand and Australia (Table 3).

Alternatives to lawns are usually inspired by different grassy ecosystems or from biomes with low growing vegetation that can withstand heat and drought. Most existing alternatives, nevertheless, are not equivalent to conventional turf-durable sod that withstands recreational pressure (trampling). The purpose of such solutions is to decrease the number of unused lawns surfaces (urban planning) and to avoid homogeneity (visual and ecological) by employing different landscape design patterns (colour and texture) as well as providing more biodiversity, and thus ecologically friendly, wildlife habitats and a healthier environment (decreased mowing and fewer greenhouse gas emissions). 
Table 3. Alternatives to lawns.

\begin{tabular}{|c|c|c|c|c|c|c|c|}
\hline Alternatives to Lawns & Germany & Sweden & UK & ${ }^{\text {a }}$ USA & ${ }^{b}$ USA & Australia & $\begin{array}{c}\text { New } \\
\text { Zealand }\end{array}$ \\
\hline Go Spontaneous & + & & & & & & \\
\hline Meadows & + & + & + & & & & \\
\hline Grass-free (tapestry lawns) & & + & + & & & & \\
\hline Pictorial meadows & + & + & + & + & $\begin{array}{c}+ \text { (road } \\
\text { plantings })\end{array}$ & & \\
\hline Naturalistic plantings & & & + & & & & \\
\hline Prairie gardens & & & & + & & & \\
\hline Swale and rain gardens plantings & + & + & + & + & + & + & + \\
\hline Xeriscape gardens/rock gardens & & & & & + & + & + \\
\hline Verge gardens and woody meadows & & & & & & + & \\
\hline $\begin{array}{c}\text { Use of appropriate native } \\
\text { groundcovers in private gardens }\end{array}$ & + & + & + & + & + & + & + \\
\hline
\end{tabular}

Notes: ${ }^{\mathrm{a}}$ USA — temperate climate states, ${ }^{\mathrm{b}}$ USA—arid climate states.

In Europe, all ideas about alternative lawns are connected to native grasslands, pasture land, or the open margins of temperate forests (which support some grasses and low growing vegetation). In Sweden and Germany, for example, there are several nurseries that specialise in producing multispecies native meadow mats made up of $70-80 \%$ grass and $20-30 \%$ native herbaceous wildflowers [22]. English landscape architects such as James Hitchmough and Nigel Dunnett introduced naturalistic plantings that combine native herbaceous and grass species with attractive non-native, flowering prairie plants from North America. These aimed at increasing biodiversity and facilitating low level of management [91].

Pictorial meadows created from flowering annual plants are increasingly popular all over Europe and the US. Often used for road (highway) plantings, such meadows are inspired by the margins of agricultural fields or by natural blossoms in dry Mediterranean ecosystems or semi-desert areas. The use of prairie plants in private gardens and public parks in the suburban Midwest of the USA (e.g., Millennium Park in Chicago) is gaining popularity in the face of increasing temperatures and lengthening drought periods (Figure 8). Similar factors are the driving force behind xeriscape gardening in California, Arizona, New Mexico, Texas, Colorado and Florida as well as in Australian cities $[87,125,126]$. Xeriscaping is a process of landscaping that reduces/eliminates/minimises the need for supplemental water from irrigation. Local plant species are being promoted as the most tolerant to such harsh conditions $[1,35,42,46,89,90]$.

The German-born "Go spontaneous" approach is connected to the essence of German urban ecology and particularly with the Berlin School. It has been developed in special abundant wasteland sites and regenerating vegetation. Studies into the capacity of urban nature to regenerate to a certain successional stage, to exhibit certain plant strategies and to provide ecosystem services, have showed success and have also fostered acceptance of the "go wild" approach to designing public spaces (Park am Gleisdreieck). Industrial habitats were "reinforced" by seeding "weeds" or leaving nature "alone" [72] (Figure 12). 


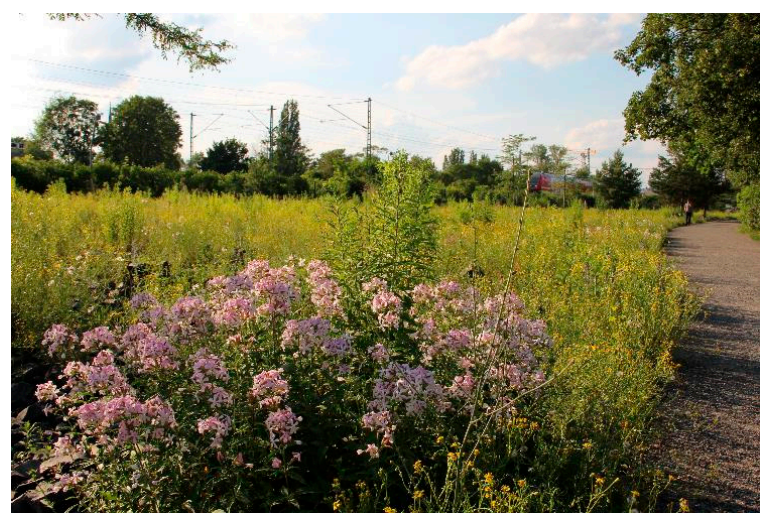

(a)

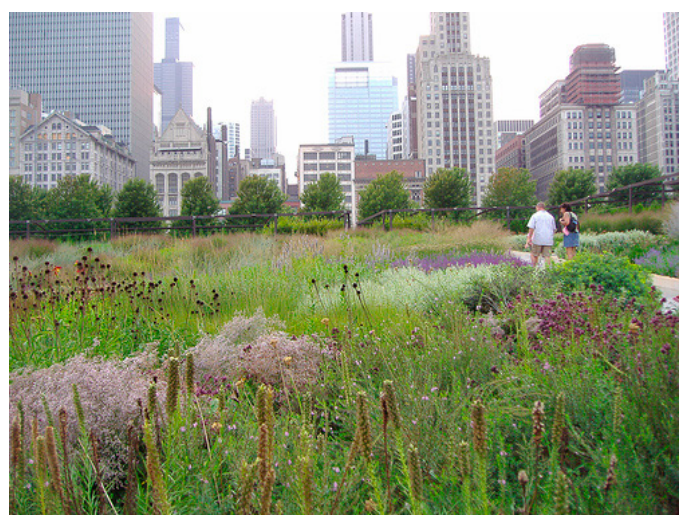

(b)

Figure 12. Spontaneous lawn in Gleisdreieck Park, Berlin (a), and the latest inspiration in the US: Lurie Garden with prairie plants in Millennium Park, Chicago (b). Photos: M. Ignatieva.

Among the tested alternatives to lawns, grass-free (tapestry) surfaces are closest to the idea of conventional turf where roots and stolons produce strong sod that can tolerate human traffic pressure. A few low-growing European native herbaceous plants (Potentilla, Prunella, Veronica, Trifoluim, Lotus, Hieracium and Polygonum aveculare), that are already present in actively visited lawns, may be used for a new generation of grass-free lawns where planting is based on a mixture low growing ground covers and forbs (Figure 13). However, such lawns require experimental trials and further research into their resistance to human traffic. Even in non-European lawns, for example in China, there are several native herbaceous species in conventional lawns that can be considered as potential candidates for creating sustainable future alternatives [4].

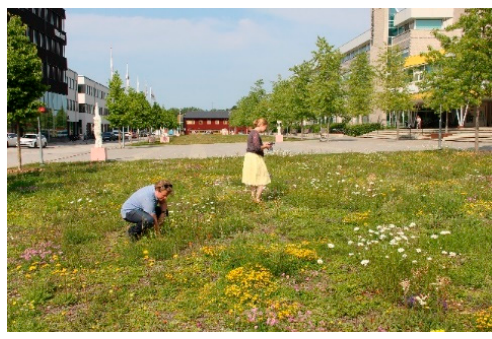

(a)

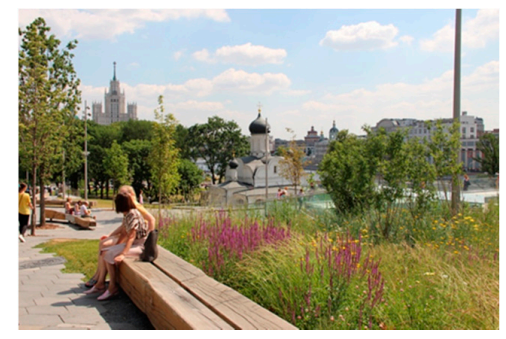

(b)

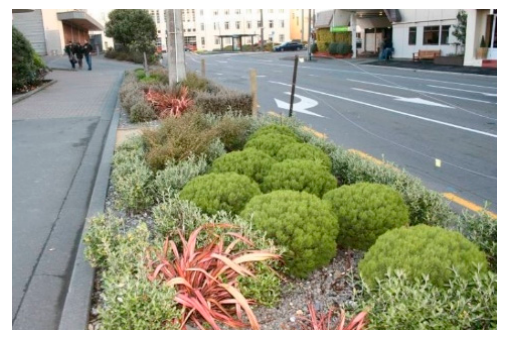

(c)

Figure 13. Nature-based solutions for urban lawns: (a) Grass-free lawn in the Ultuna campus of Swedish University of Agricultural Sciences in Uppsala (Sweden); (b) Steppe Garden in Zaryadye Park in Moscow, Russia; (c) native plants for traffic islands in Wellington (New Zealand). Photos: M. Ignatieva, Dushkova.

In Australia, one particular alternative to lawns, the verge garden, uses native plants in the strip of council land between the street and the footpath in suburban areas. Recently, Perth City Council in Western Australia has encouraged people to transform their verge into native low maintenance gardens using a waterwise approach and planting low-growing native plants instead of lawns. Ongoing interdisciplinary research in Perth is studying the social motives of suburban homeowners who are willing to transform their front verges into native gardens [88].

Another approach, introduced only a few years ago and inspired by the pictorial and naturalistic meadow movement in the UK, is "woody meadows". The idea behind the "woody meadow" is to plant low-growing native plants (herbaceous plants and lower shrubs) within urban "designed" landscapes. "Modelled on natural heathland plant communities across southern Australia, the aim of the project is to create visually interesting landscapes that require little ongoing maintenance, such as irrigation and labour, to sustain them" [127]. This project is a research collaboration between the 
University of Sheffield in England, the University of Melbourne and the City of Melbourne. Now the "woody meadow" will be implemented in Perth, using unique, Western Australian plants. Directly influenced by alternative thinking and designing of lawns in England, the idea is to create "a beautiful, meadow-like appearance", similar to what has been done in Europe.

\section{Discussion}

There is a new landscape architecture approach referred to as "biodiversinesque", which promotes a special design style for sustainable landscape design [72]. It is based on multiscale design with particular emphasis on the mesoscale, or the neighbourhood or park level, and is a detailed design where biodiversity and dynamic ecological process-succession can be implemented and monitored. One fundamental difference of this new vision from other approaches is the appreciation of the complexity of biodiversity instead of the narrower native vs. exotic plants debate. This new design language incorporates the dynamic character of urban biotopes and is believed to make a difference that will be understood and appreciated by people.

When promoting a new generation of nature-based lawns, such novel alternatives to lawns should be vastly different from conventional lawns in terms of being more cost-effective, biodiverse, trample-resistant, and stable under extreme weather conditions. At the same time, they should remain connected to the social needs of their users such as certain lawn qualities, amenities of the green space and different recreational activities. Such novel lawns should serve as valuable and resilient parts of urban green infrastructure in growing cities. Each novel nature-based solution should, on the one hand, be based on natural succession processes that occur within lawn plant communities and local indigenous plant communities and on the other hand from surrounding "designed" ecosystems [22]. The idea is to explore nature's dynamic processes and use this knowledge to address specific problems such as lawn management.

These complex approaches require careful study of existing conventional lawns, their structure, composition, soil quality and hydrological capacity, as well as an establishment and management regime (irrigation, fertilisation, pesticide application, aeration, etc.). One essential component of new research into lawn alternatives should be questionnaire surveys and a qualitative analysis of people's attachments to lawns (through interviews and focus groups). The methodology of researching lawns can be quite universal with some interpretation of the local environmental and social parameters.

However, alternative nature-based solutions should be strictly city- and country-specific. For example, with European urban ecosystems, there is much more opportunity to develop drought and trample resistant plants. Some local plants are already established in intensively used parks as a result of native succession. Many of the "old" lawns in Europe which have existed for several decades and where natural successional stages have occurred could be researched and mimicked in experimental sites.

In the southern hemisphere, especially in Australia, the attachment of urban dwellers to lawns cannot be ignored. There are two "natures" that are defined by a sharp boundary and a lack of existing research of "designed and managed" nature. In order to solve the existing lawn problem and improve ecosystem services, different research directions should be taken. Australian flora is one of the most unique in the world. For example, City of Perth is located in one of the world's 35 internationally recognised biodiversity hotspots. We can search for native plants that could be experimentally tested for their capability to withstand high recreational pressure. In the meantime, sustainable lawn management and careful water sensitive design of lawns should be a priority. Education of urban dwellers on how to water private and public gardens and how to select drought-tolerant turf grasses can be an intermediate measure. One important goal of future urban "designed" landscapes should be changing the "green" lawn psychology to a greater appreciation of the Australian native plant colours, i.e., the olive greens, browns, and yellows, and to view these as signs of healthy sustainable urban environments that can adapt better to a changing climate. 
Globally, the role of urban planners, geographers and landscape designers is more important than ever before. They need to solve the question of how to move from the current strategy of the "lawnscape" as an element of urban open spaces to more balanced, ecologically-based urban planning and design. One of the most important factors in creating this new generation of sustainable lawns is raising the awareness of the public about the possibilities of different lawn typologies and the necessity to see a place for "wild nature" in lawns. Another global challenge will be instigating interdisciplinary research projects into lawn alternatives and providing practical outcomes.

Our vision of future sustainable lawns is based on a complex hybrid approach (Table 4). Such lawns would retain their essence- their durable surface (the equivalent of turf) but be created by plants (grasses, herbaceous species and/or ground covers) that can withstand recreational pressure. At the same time, alternatives to lawns should also rely on a whole range of sustainable planning, design, and management strategies. Most likely lawn as a phenomenon will have a long life in future urban ecosystems. This is a time for creating a new conceptual framework for researching lawns.

Table 4. Redesigning lawns, a complex approach towards sustainable lawns.

\begin{tabular}{|c|c|c|c|}
\hline Urban Planning & Landscape Design & Ecological Design & Maintenance Approach \\
\hline $\begin{array}{l}\text { Reduce conventional } \\
\text { lawns by sustainable } \\
\text { planning of green areas } \\
\text { and green infrastructure } \\
\text { and new design styles }\end{array}$ & $\begin{array}{c}\text { Rethink spatial } \\
\text { composition (avoid the } \\
\text { homogenous } \\
\text { mono-species approach), } \\
\text { choice of appropriate, } \\
\text { site-related plants }\end{array}$ & $\begin{array}{l}\text { Mimic spatial structure } \\
\text { and composition of } \\
\text { existing resistant } \\
\text { biodiverse lawns and } \\
\text { surrounding native } \\
\text { ecosystems that can be } \\
\text { used as inspiration }\end{array}$ & $\begin{array}{l}\text { Self-sustaining system, locally } \\
\text { driven (climate, culture and } \\
\text { economic appropriateness) } \\
\text { cutting the regime approach } \\
\text { by reinforcing local } \\
\text { biodiversity. Sustainable } \\
\text { management (appropriate soil } \\
\text { preparation, appropriate } \\
\text { mowing regime, use of electric } \\
\text { or robotic mowers and smart } \\
\text { irrigation schemes) }\end{array}$ \\
\hline
\end{tabular}

\section{Conclusions}

To fill the gaps in our understanding of lawn as a global phenomenon, we propose a framework for future interdisciplinary study and nature-based solutions for lawns, which will be based on data from cities in different climatic zones and social, cultural and geographical conditions (Figure 14).

Lawn should be studied as specifically designed urban habitats/biotopes as well as in cultural and social terms, i.e., complex analysis of ecosystem service flows, related social norms and expectations, and uses and behaviours. This should be achieved by applying the most recent methods and theoretical concepts such as resilience, sustainability [128], biocultural diversity [129], nature-based solutions [20,21,124], the "biodiversinesque" landscape architectural style [72] and ecological landscaping [92]. There is a paucity of research on possible nature-based solutions to lawns and the existing urban plant communities-man-made but influenced by natural and anthropogenic factors-and their successional stages. So far, there have been no attempts to understand the functioning mechanisms of urban lawns as a unique dynamic ecological system and to model sustainable landscape design solutions for different types of lawns. We suggest a novel vision of lawn alternatives a local community-driven approach based on existing native and urban plant ecosystems.

The overall aim of future research on lawns should be to investigate, analyse and understand the phenomenon of lawns from different environmental, socio-cultural and design perspectives, as well to empirically explore, suggest and test different locally adapted nature-based solutions. Studies should identify biodiversity characteristics (lawn composition and structure) as well as research plant communities similar to lawns. The aim is to find alternatives, which have high biodiversity and ecosystem service flows, and that are trample resistant, socially acceptable and offer improved overall resilience to climate change and its effects on urban green infrastructure. 


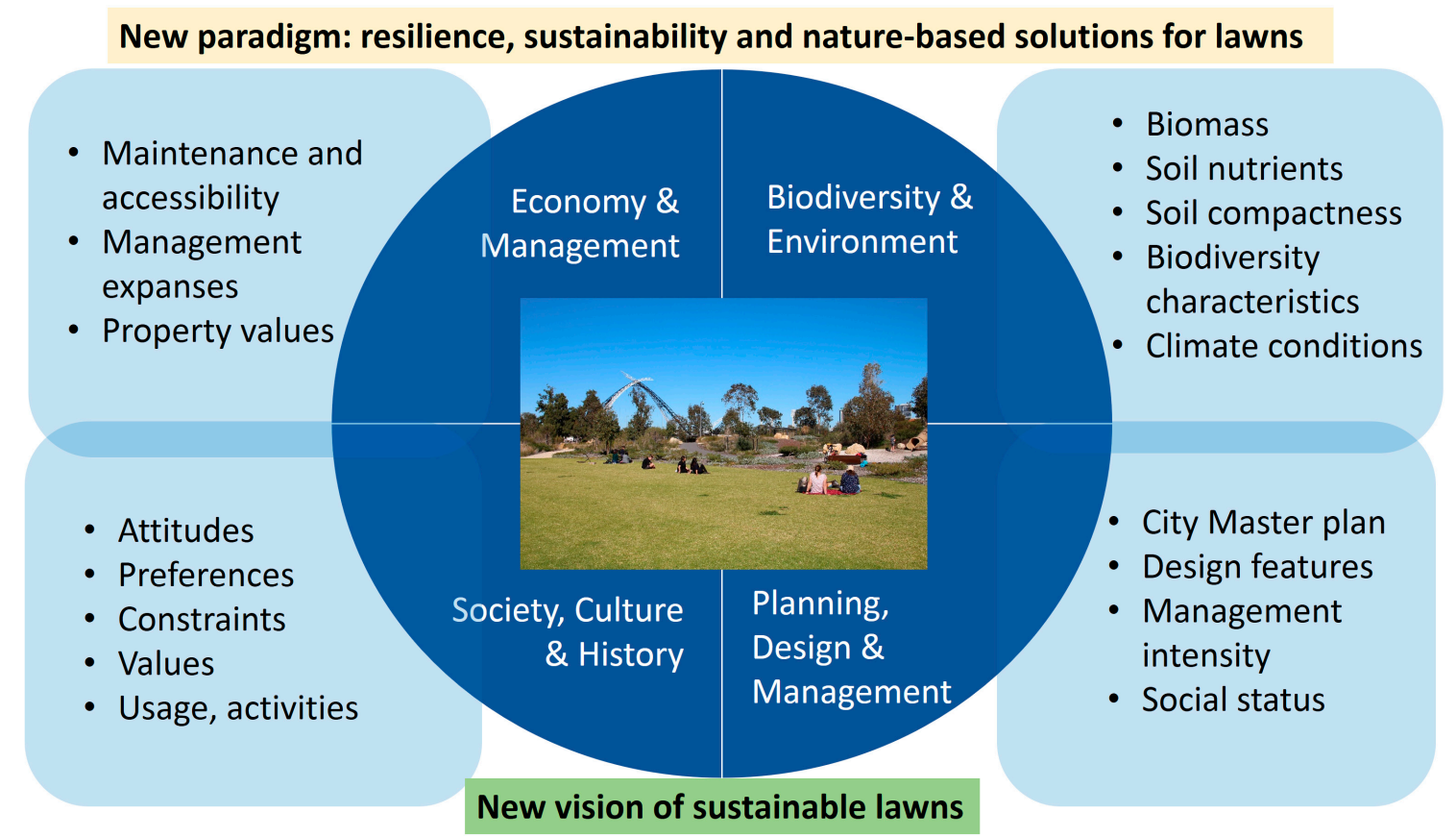

Figure 14. Proposed interdisciplinary research framework for lawns as a complex phenomenon (Source: the authors).

Author Contributions: Conceptualization, M.I., D.D. and D.H.; methodology, M.I., D.D. and D.H.; validation, D.H. and D.D.; formal analysis M.I. and D.D.; investigation, M.I., D.D., D.H.; resources M.I., D.D.; data curation and interpretation of results, M.I., D.D.; writing — original draft preparation, M.I., D.D. and D.H.; writing-review and editing, M.I., D.D., D.H. and A.H.; visualization, D.D.; supervision, D.H.; project administration, M.I.; funding acquisition, M.I. and D.H. The concept of "two natures" and the conceptual vision of lawn alternatives was suggested by M.I. All authors have read and agree to the published version of the manuscript.

Funding: This research was funded by several sources: M.I. research-by the University of Western Australia (UWA) FABLE research grant funded from 2018 to 2019; by Swedish Research Foundation FORMAS (225-2012-1369) "Lawns as a cultural and ecological phenomenon" (2013-2017) and by Swedish University of Agricultural Sciences SLU Climate Project: Towards sustainable lawns: searching for alternative cost effective and climate friendly lawns in Ultuna Campus (2016-2017); D.H. research was supported as part of the project ENABLE, funded through the 2015-2016 BiodivERsA COFUND call for research proposals, with the national funders The Swedish Research Council for Environment, Agricultural Sciences, and Spatial Planning, Swedish Environmental Protection Agency, German Aeronautics and Space Research Centre, National Science Centre (Poland), The Research Council of Norway and the Spanish Ministry of Economy and Competitiveness. In addition, Dagmar benefited from the GreenCityLabHue Project (FKZ 01LE1910A) and the CLEARING HOUSE (Collaborative Learning in Research, Information-sharing and Governance on How Urban forest-based solutions support Sino-European urban futures) Horizon 2020 project (No 1290/2013). D.D. and D.H. research was founded by the Horizon 2020 Framework Programme of the European Union, research and innovation project "CONNECTING Nature-COproductioN with NaturE for City Transitioning, Innovation and Governance", Grant Agreement No 730222.

Acknowledgments: We thank participants of the international workshop "Urban Biodiversity and Nature-Based Design: Methodology and Practical Applications for Interdisciplinary Research" orginised by the Geography Department of Humboldt university Berlin on the 28-29 November 2019 in Berlin for a lot of inspiration for the future transdisciplinary research on lawns. We thank Daniel Martin (UWA) for helping with obtaining numbers on water usage in Perth. The authors also extend great gratitude to the anonymous reviewers and editors for their helpful reviews and critical comments.

Conflicts of Interest: The authors declare no conflict of interest.

\section{References}

1. Ignatieva, M.; Hedblom, M. An alternative urban green carpet: How can we move to sustainable lawns in a time of climate change? Science 2018, 362, 148-149. [CrossRef] [PubMed]

2. Haase, D.; Nuissl, H. Does urban sprawl drive changes in the water balance and policy? The case of Leipzig (Germany) 1870-2003. Landsc. Urban Plan. 2007, 80, 1-13. [CrossRef] 
3. Hedblom, M.; Lindberg, F.; Vogel, E.; Wissman, J.; Ahrné, K. Estimating urban lawn cover in space and time: Case studies in three Swedish cities. Urban Ecosyst. 2017, 20. [CrossRef]

4. Yang, F.; Ignatieva, M.; Larsson, A.; Zhang, S.; Ni, N. Public perceptions and preferences regarding lawns and their laternatives in China: A case study of Xi'an. Urban For. Urban Green. 2019, 46, 126478. [CrossRef]

5. Thompson, G.L.; Kao-Kniffin, J. Applying Biodiversity and Ecosystem Function Theory to Turfgrass Management. Crop Sci. 2017, 57, 238-248. [CrossRef]

6. Cumming, J. Environmental Assessment of the Australian Turf Industry. Hort Innovation Project No. TU16000 Benchmarking Report. 2018. Available online: https://www.horticulture.com.au/globalassets/hortinnovation/resource-assets/tu16000-benchmarking-report.pdf (accessed on 1 November 2019).

7. Haase, D.; Haase, A.; Rink, D. Conceptualising the nexus between urban shrinkage and ecosystem services. Landsc. Urban Plan. 2014, 132, 159-169. [CrossRef]

8. Haase, D.; Larondelle, N.; Andersson, E.; Artmann, M. A quantitative review of urban ecosystem services assessment: Concepts, models and implementation. AMBIO 2014, 43, 413-433. [CrossRef]

9. Haase, A.; Wolff, M.; Rink, D. From shrinkage to regrowth. The nexus between urban dynamics, land use change and ecosystem service provision. In Urban Transformations-Sustainable Urban Development towards Resource Efficiency, Quality of Life and Resilience; Future City Series; Kabisch, S., Ed.; Springer: Berlin, Germany, 2018; pp. 197-219.

10. Haase, D.; Haase, A.; Rink, D.; Quanz, J. Shrinking Cities and Ecosystem Services: Opportunities, Planning, Challenges, and Risks. In Atlas of Ecosystem Services; Schröter, M., Ed.; Springer: Cham, Switzerland, 2019; pp. 271-277. [CrossRef]

11. Groffman, P.M.; Cavender-Bares, J.; Bettez, N.D. Ecological homogenization of urban USA. Front. Ecol. Environ. 2014, 12, 74-81. [CrossRef]

12. McKinney, M.L. Urbanization as a major cause of biotic homogenization. Biol. Conserv. 2006, 11, $247-260$. [CrossRef]

13. Wheeler, M.M.; Neil, C.; Groffman, P.M. Continental-scale homogenization of residential lawn plant communities. Landsc. Urb. Plan. 2017, 165, 54-63. [CrossRef]

14. NOAA-The US National Oceanic and Atmospheric Administration. July 2019 Was Hottest Month on Record for the Planet; NOAA: Silver Spring, MD, USA, 2019; Available online: https://www.clickondetroit. com/weather-center/2019/08/15/noaa-july-2019-was-hottest-month-on-record-for-the-planet/ (accessed on 11 November 2019).

15. Goosse, H.; Kay, J.E.; Armour, K.C.; Bodas-Salcedo, A. Quantifying climate feedbacks in polar regions. Nat. Commun. 2018, 9, 1919. [CrossRef] [PubMed]

16. Hogue, T.; Pinceti, S. Are you watering your lawn? High-resolution data may help to devise effective water conservation strategies in urban areas around the world. Science 2015, 348, 6241.

17. Borrelle, S.B.; Rochman, C.M.; Liboiron, M.; Bond, A.L.; Lusher, A.; Bradshaw, H.; Provencher, J.F. Why we need an international agreement on marine plastic pollution. Proc. Natl. Acad. Sci. USA 2017, 114, 9994-9997. [CrossRef] [PubMed]

18. Fleming, P.R.; Forrester, S.E.; McLaren, N.J. Understanding the effects of decompaction maintenance on the infill state and play performance of third-generation artificial grass pitches. Proc. Inst. Mech. Eng. Part P J. Sports Eng. Technol. 2015, 229, 169-182. [CrossRef] [PubMed]

19. Kaminski, I. Turf It out: Is It Time to Say Goodbye to Artificial Grass? The Guardian. 2 August 2019. Available online: https://www.theguardian.com/cities/2019/aug/02/turf-it-out-is-it-time-to-say-goodbye-to-artificialgrass (accessed on 1 November 2019).

20. EC-European Commission. Towards an EU Research and Innovation Policy Agenda for Nature-Based Solutions E Re-Naturing Cities. Final Report of the Horizon2020 Expert Group on Nature-Based Solutions and Re-Naturing Cities; European Commission: Brussels, Belgium, 2015.

21. Raymond, C.M.; Berry, P.; Breil, M.; Nita, M.R.; Kabisch, N. An Impact Evaluation Framework to Support Planning and Evaluation of Nature-Based Solutions Projects. Report Prepared by the EKLIPSE Expert Working Group on Nature-Based Solutions to Promote Climate Resilience in Urban Areas; Centre for Ecology \& Hydrology: Wallington, UK, 2017.

22. Ignatieva, M. Lawn Alternatives in Sweden: From Theory to Practice; Manual; Swedish University of Agricultural Sciences: Uppsala, Sweden, 2017. 
23. Ignatieva, M.; Meurk, C.; van Roon, M.; Simcock, R.; Stewart, G. Urban Greening Manual. How to Put Nature in Our Neighbourhoods: Application of Low Impact Urban Design and Development (LIUDD) Principles, with a Biodiversity Focus, for New Zealand Developers and Homeowners; Landcare Research Sciences Series No.35; Manaaki Whenua Press: Lincoln, NZ, USA, 2008.

24. Milesi, C.; Running, S.W.; Elvidge, C.D.; Dietz, J.B.; Tuttle, B.T.; Nemani, R.R. A strategy for Mapping and Modeling of biochemical turfgrasses in the United States. Environ. Manag. 2005, 36, 426-438. [CrossRef]

25. Robbins, P.; Birkenholtz, T. Turfgrass revolution: Measuring the expansion of the American lawn. Land Use Policy 2003, 20, 181-194. [CrossRef]

26. Gaston, K.J.; Warren, P.H.; Thompson, K. Urban Domestic Gardens (IV): The Extent of the Resource and its Associated Features. Biodivers. Conserv. 2005, 14, 3327. [CrossRef]

27. Hahs, A.; McDonnell, M. Composition of the plant community in remnant patches of grassy woodland along an urban-rural gradient in Melbourne, Australia. Urban Ecosyst. 2007, 10, 355-377. [CrossRef]

28. Lindenmayer, D.; Fisher, J.; Felton, A.; Crane, M.; Michael, D.; Macgregor, C.; Montague-Drake, R.; Manning, A.; Hobbs, R. Novel ecosystem resulting from landscape transformation create dilemmas for modern conservation practice. Conserv. Lett. 2008, 1, 129-135. [CrossRef]

29. Müller, N. Lawns in German cities. A phytosociological comparison. In Urban Ecology; Sukopp, H., Hejnỳ, S., Kowarik, I., Eds.; SPB Academic Publishing: The Hague, The Netherlands, 1990; pp. 209-222.

30. Stewart, G.H.; Meurk, C.D.; Ignatieva, M.E.; Buckley, H.L.; Magueur, A.; Case, B.S.; Hudson, M.; Parker, M. Urban Biotopes of Aotearoa New Zealand (URBANZ) II: Floristics, biodiversity and conservation values of urban residential and public woodlands, Christchurch. Urban For. Urban Green. 2009, 8, 149-162. [CrossRef]

31. Sukopp, H.; Kowarik, I. Urban Ecology; SPB Academic Publishing: The Hague, The Netherlands, 1990.

32. Threlfall, C.; Walker, K.; Williams, N.; Hahs, A.; Mata, L.; Stork, N.; Livesley, S.J. The conservation value of urban green space habitats for Australian native bee communities. Biol. Conserv. 2015, 187, 240-248. [CrossRef]

33. Amani-Beni, M.; Zhang, B.; Xie, G.; Xu, J. Impact of urban park's tree, grass and waterbody on microclimate in hot summer days: A case study of Olympic Park in Beijing, China. Urban For. Urban Green. 2018, 32, 1-6. [CrossRef]

34. Armson, D.; Stringer, P.; Ennos, A.R. The effect of street trees and amenity grass on urban surface water runoff in Manchester, UK. Urban For. Urban Green. 2013, 12, 282-286. [CrossRef]

35. Beard, J.B.; Green, R.L. The role of turfgrasses in environmental protection and their benefits to humans. J. Environ. Qual. 1994, 23, 452-460. [CrossRef]

36. Brunton, E.; Srivastava, S.; Burnett, S. Spatial ecology of an urban eastern grey kangaroo (Macropus giganteus) population: Local decline driven by kangaroo-vehicle collisions. Wildl. Res. 2018, 45. [CrossRef]

37. Burgin, S. What about biodiversity? Redefining urban sustainable management to incorporate endemic fauna with particular reference to Australia. Urban Ecosyst. 2016, 19, 669-678. [CrossRef]

38. Fischer, L.; Lippe, M.; Kowarik, I. Urban land use types contribute to grassland conservation: The example of Berlin. Urban For. Urban Green. 2013, 12, 263-272. [CrossRef]

39. Fischer, L.K.; Eichfeld, J.; Kowarik, I.; Buchholz, S. Disentangling urban habitat and matrix effects on wild bee species. PeerJ 2016, 4, e2729. [CrossRef]

40. Johnson, P.G. Priorities for Turfgrass management and education to enhance urban sustainability worldwide. J. Dev. Sustain. Agric. 2013, 8, 63-71. [CrossRef]

41. Lele, S.; Springate-Baginski, O.; Lakerveld, R.; Deb, D.; Dash, P. Ecosystem Services: Origins, Contributions, Pitfalls, and Alternatives. Conserv. Soc. 2013, 11, 343-358. [CrossRef]

42. Monteiro, J.A. Ecosystem services from turfgrass landscapes. Urban For. Urban Green. 2017, 26, $151-157$. [CrossRef]

43. Stirling, G.; Stirling, M.; Giblin-Davis, R.M. Distribution of southern sting nematode, Ibipora lolii (Nematoda: Belonolaimidae), on turfgrass in Australia and its taxonomic relationship to other belonolaimids. Nematology 2013, 15, 401-415. [CrossRef]

44. Trigger, D.; Mulcock, J. Native versus exotic: Cultural discourses about flora, fauna and belonging in Australia. In Sustainable Planning and Development: The Sustainable World; Kungolos, A., Brebbia, C., Beriatos, E., Eds.; Wessex Institute of Technology Press: Southampton, UK, 2005; Volume 6, pp. 1301-1310.

45. Wang, Z.-H.; Zhao, X.; Yang, J.; Song, J. Cooling and energy saving potentials of shade trees and urban lawns in a desert city. Appl. Energy 2016, 161, 437-444. [CrossRef] 
46. Wastian, L.; Unterweger, P.A.; Betz, O. Influence of the reduction of urban lawn mowing on wild bee diversity (Hymenoptera, Apoidea). J. Hymenopt. Res. 2016, 49, 51-63.

47. Campagne, C.S.; Roche, P.K.; Salles, J.-M. Looking into Pandora's Box: Ecosystem disservices assessment and correlations with ecosystem services. Ecosyst. Serv. 2018, 30, 126-136. [CrossRef]

48. Döhren, P.; Haase, D. Ecosystem disservices research: A review of the state of the art with a focus on cities. Ecol. Indic. 2015, 52, 490-497. [CrossRef]

49. Dunn, R.R. Global Mapping of ecosystem disservices: The unspoken reality that nature sometimes kills us. Biotropica 2010, 42, 555-557. [CrossRef]

50. Lyytimäki, J. Ecosystem disservices: Embrace the catchword. Ecosyst. Serv. 2015, 12, 136. [CrossRef]

51. Müller, N.; Sukopp, H. Influence of different landscape design styles on plant invasions in Central Europe. Landsc. Ecol. Eng. 2016, 12, 151. [CrossRef]

52. Priest, M.W.; Williams, D.J.; Bridgman, H.A. Emission from in-use lawn-mowers in Australia. Atmos. Environ. 2000, 34, 657-664. [CrossRef]

53. Runfola, D.; Polsky, C.; Nicolson, C.; Giner, N.; Pontius, R.; Krahe, J.; Decatur, A. A growing concern? Examining the influence of lawn size on residential water use in suburban Boston, MA, USA. Landsc. Urban Plan. 2013, 119, 113-123. [CrossRef]

54. Shackleton, C.M.; Ruwanza, S.; Sinasson Sanni, G.K.; Bennett, S.; De Lacy, P.; Modipa, R.; Mtati, N.; Sachikonye, M.; Thondhlana, G. Unpacking Pandora's Box: Understanding and Categorising Ecosystem Disservices for Environmental Management and Human Wellbeing. Ecosystems 2016, 19, 587-600. [CrossRef]

55. Schapel, A.; Reseigh, J.; Wurst, M.; Mallants, D.; Herrmann, T. Offsetting Greenhouse Gas Emissions through Increasing Soil Organic Carbon in SA Clay-Modified Soils: Knowledge Gap Analysis; Technical Report Series No. 18/05; Goyder Institute for Water Research: Adelaide, SA, Australia, 2018.

56. Sharma, M.L.; Herne, D.E.; Byrne, J.D.; Kin, P.G. Nutrient Discharge beneath urban lawns to a sandy coastal aquifer, Perth, Western Australia. Hydrogeol. J. 1996, 4, 103-117. [CrossRef]

57. Elgizawy, E.M. Expectations towards green lawns to enhance quality of life and workplaces. Procedia Environ. Sci. 2016, 34, 131-139. [CrossRef]

58. Han, X.; Burton, O.R.; Sternudd, C.; Li, D. Public Attitudes about Urban Lawns: Social Opportunities Provided by Urban Lawns in Lund, Sweden. In Proceedings of the 2013 International Academic Workshop on Social Science, Changsha, China, 18-20 October 2013; Shao, X., Ed.; Atlantis Press: Paris, France, 2013; pp. 1046-1054. [CrossRef]

59. Jenkins, V.S. The Lawn: A History of an American Obsession; Smithsonian Institution: Washington, DC, USA, 1994.

60. Pisa, J. The lawn grew too quickly! Perception of rural idyll by Czech amenity migrants. Geoscape 2019, 13, 55-67. [CrossRef]

61. Poškus, M.; Poškienè, D. The grass is greener: How greenery impacts the perceptions of urban residential property. Soc. Inq. Into Well-Being 2015, 1, 22-31. [CrossRef]

62. Rall, E.; Bieling, C.; Zytynska, S.; Haase, D. Exploring city-wide patterns of cultural ecosystem service perceptions and use. Ecol. Indic. 2017, 77, 80-95. [CrossRef]

63. Ramer, H.; Nelson, K.C.; Spivak, M. Exploring park visitor perceptions of "flowering bee lawns" in neighborhood parks in Menapolis, MN, US. Landsc. Urban Plan. 2019, 189, 117-128. [CrossRef]

64. Robbins, P. Lawn People: How Grasses, Weeds, and Chemicals Make Us Who We Are; Temple University Press: Philadelphia, PA, USA, 2007.

65. Sewel, S.; McCallister, D.; Gaussoin, R.; Wortmann, C. Lawn management practices and perceptions of residents in 14 Sandpit Lakes of Nebraska. J. Ext. 2010, 48, 2 Rib4.

66. Teysott, G. The American Lawn, 1st ed.; Princeton Architectural Press: New York, NY, USA, 1999.

67. Yang, F.; Ignatieva, M.; Larsson, A.; Xiu, N.; Zhang, S. Historical Development and Practices of Lawns in China. Environ. Hist. 2019, 25, 23-54. [CrossRef]

68. Antrop, M. Landscape change and the urbanization process in Europe. Landsc. Urban Plan. 2004, 7, 9-26. [CrossRef]

69. Pondichie, F.A. Globalization Elements in Romanian Cities: Searching for Sustainable Solutions. Master's Thesis, Uppsala University, Uppsala, Sweden, 2012.

70. Payne, S.K.; Bruce, N. Exploring the relationship between urban quiet areas and perceived restorative benefits. Int. J. Environ. Res. Public Health 2019, 16, 1611. [CrossRef] [PubMed] 
71. Stolz, J.; Schaffer, C. Salutogenic affordances and sustainability: Multiple benefits with edible forest gardens in urban green spaces. Front. Psychol. 2018, 9, 2344. [CrossRef] [PubMed]

72. Ignatieva, M. Biodiversity-friendly designs in cities and towns: Towards a global biodiversinesque style. In Urban Biodiversity: From Research to Practice; Ossola, A., Niemelä, J., Eds.; Routledge (Routledge Studies in Urban Ecology): Abingdon, UK, 2018; pp. 216-235.

73. Gaynor, A. Lawnscaping Perth: Water Supply, Gardens, and Scarcity, 1890-1925. J. Urban Hist. 2017. [CrossRef]

74. Hipple, W.J., Jr. The Beautiful, the Sublime and the Picturesque in Eighteenth-Century British Aesthetics Theory; Southern Illinois University Press: Carbondale, IL, USA, 1957.

75. Robinson, S.K. Inquiry into the Picturesque; The University of Chicago Press: Chicago, IL, USA, 1991.

76. Greenbaum, A. Lawn as a Site of Environmental Conflict. Ph.D. Thesis, Department of Sociology, York University, Toronto, ON, Canada, 2000.

77. Harari, Y.N. Homo Deus: A Brief History of Tomorrow; Random House: New York, NY, USA, 2016.

78. Trudgill, S.; Jeffery, A.; Parker, J. Climate Change and the Resilience of the Domestic Lawn. Appl. Geogr. 2010, 30, 177-190. [CrossRef]

79. Alumai, A. Urban Lawn Management: Addressing the Entomological, Agronomic, Economic, and Social Drivers. Ph.D. Thesis, Ohio State University, Columbus, OH, USA, 2008.

80. Chawla, S.L.; Agnihotri, R.; Patel, M. Turfgrass: A Billion Dollar Industry. In Proceedings of the National Conference on Floriculture for Rural and Urban Prosperity in the Scenario of Climate Change, Gangtok, India, 16-18 February 2018; pp. 30-35.

81. Ignatieva, M. Design and future of urban biodiversity. In Urban Biodiversity and Design; Müller, N., Werner, P., Kelcey, J., Eds.; Wiley-Blackwell: Oxford, UK, 2010; pp. 118-144.

82. Ignatieva, M.; Ahrné, K. Biodiverse green infrastructure for the 21st century: From "green desert" of lawns to biophilic cities. J. Archit. Urban. 2013, 37, 1-9. [CrossRef]

83. Pineo, R.; Barton, S. Turf Grass Madness: Reasons to Reduce the Lawn in Your Landscape. Sustain. Landsc. Ser. 2010, 130. Available online: https://cdn.canr.udel.edu/wp-content/uploads/sites/16/2018/03/12024155/ Turf_Grass_Madness.pdf (accessed on 18 October 2019).

84. Steinberg, T. American Green: The Obsessive Quest for the Perfect Lawn; W.W. Norton \& Co: New York, NY, USA, 2006.

85. Wasowski, A.; Wasowski, S. The Landscaping Revolution: Garden with Mother Nature, Not against Her; McGraw-Hill/The Contemporary Gardener: New York, NY, USA, 2002.

86. Wasowski, S.; Wasowski, A. Requiem for a Lawnmower: Gardening in a Warmer, Drier World; Taylor Trade Publications: Lanham, MD, USA, 2004.

87. Wilson, C.; Feuch, J.R. Xeriscaping: Creative Landscaping; Colorado State University Extension: Fort Collins, CO, USA, 2018.

88. Zollner, M. Leading the way for urban green spaces: The CAUL Hub in Western Australia. Urban Beat 2018, 8, 3-4.

89. Bormann, H.F.; Balmori, D.; Geballe, G.T. Redesigning the American Lawn: A Search for Environmental Harmony, 2nd ed.; Yale University Press: New Haven, CT, USA, 2001.

90. Daniels, S. The Wildlawn Handbook: Alternatives to the Traditional Front Lawn; Macmillan Publishing Company: New York, NY, USA, 1995.

91. Hitchmough, J. Naturalistic herbaceous vegetation for urban landscapes. In The Dynamic Landscape; Dunnett, N., Hitchmough, J., Eds.; Taylor \& Francis: London, UK, 2004; pp. 130-183.

92. Sprajcar, J. More than Just a Yard. Ecological Landscaping Tools for Massachusetts Homeowners; Massachusetts Executive Office of Energy and Environmental Affairs: Boston, MA, USA, 2017.

93. Brooks, A.; Francis, R. Artificial lawn people. Environ. Plan. E Nat. Space 2019, 2, 548-564. [CrossRef]

94. Loveday, J.; Loveday, G.; Byrne, J. Seasonal and Diurnal Surface Temperatures of Urban Landscape Elements. Sustainability 2019, 11, 5280. [CrossRef]

95. Higgs, E. Novel and designed ecosystems. Restor. Ecol. 2016, 25, 8-13. [CrossRef]

96. Hobbs, R.J.; Arico, S.; Aronson, J.; Baron, J.S.; Bridgewater, P. Novel ecosystems: Theoretical and management aspects of the new ecological world order. Glob. Ecol. Biogeogr. 2006, 15, 1-7. [CrossRef]

97. Kowarik, I. Novel urban ecosystems, biodiversity, and conservation. Environ. Pollut. 2011, 159, $1974-1983$. [CrossRef] [PubMed] 
98. Norton, B.; Couts, A.; Livesley, S.; Harris, R.; Hunter, A.; Williams, N. Planning for cooler cities: A framework to prioritise green infrastructure to mitigate high temperatures in urban landscapes. Landsc. Urban Plan. 2015, 134, 127-138. [CrossRef]

99. Yang, F.; Ignatieva, M.; Wissman, J.; Ahrné, K.; Zhang, S.; Zhu, S. Relationships between multi-scale factors, plant and pollinator diversity, and composition of park lawns and other herbaceous vegetation in a fast growing megacity of China. Landsc. Urban Plan. 2019, 185, 117-126. [CrossRef]

100. Wilson, J. Contextual Historical Overview for Christchurch City; Christchurch City Council: Christchurch, New Zealand, 2005.

101. Aitken, R.; Looker, M. The Oxford Companion to Australian Gardens; Oxford University Press in Association with the Australian Garden History Society: South Melbourne, VIC, Australia; Oxford, UK, 2002.

102. Ignatieva, M.; Eriksson, F.; Eriksson, T.; Berg, P.; Hedblom, M. The lawn as a social and cultural phenomenon in Sweden. Urban For. Urban Green. 2017, 21, 213-223. [CrossRef]

103. Daniels, B.; Zaunbrecher, B.; Paas, B. Assessment of urban green space structures and their quality from a multidimensional perspective. Sci. Total Environ. 2018, 615, 1364-1378. [CrossRef]

104. Kabisch, N.; Qureshi, S.; Haase, D. Human-environment interactions in urban green spaces-A systematic review of contemporary issues and prospects for future research. Environ. Impact Assess. Rev. 2015, 50, $25-34$. [CrossRef]

105. Kabisch, N.; Haase, D. Green justice or just green? Provision of urban green spaces in Berlin, Germany. Landsc. Urban Plan. 2014, 122, 129-139. [CrossRef]

106. Rink, D.; Rumpel, P.; Slach, O.; Cortese, C.; Violante, A.; Bini, P.; Haase, A.; Mykhnenko, V.; Nadolu, B.; Couch, C.; et al. Governance of Shrinkage-Lessons Learnt from Analysis for Urban Planning and Policy. EU 7 FP Project Shrink Smart (Contract No. 225193), WP7. 2012. Available online: https: //www.ufz.de/export/data/400/39029_WP7_D13_14_15_FINAL_2.pdf (accessed on 16 October 2019).

107. Haase, D.; Dushkova, D.; Haase, A.; Kronenberg, J. Green infrastructure in postsocialist cities: Evidence and experiences from Russia, Poland and Eastern Germany. In Post-Socialist Urban Infrastructures; Tuvikene, T., Sgibnev, W., Neugebauer, C.S., Eds.; Routledge: Abingdon, UK, 2019; pp. 105-122.

108. Available online: https://www.resilientsouth.com/urban-heat (accessed on 18 October 2019).

109. Available online: https://www.watercorporation.com.au/-/media/files/residential/about-us/our-performance/ annual-report-2018/water\%20corporation\%202018\%20annual\%20report.pdf (accessed on 16 December 2019).

110. Francis, R.A. Artificial lawns: Environmental and societal considerations of an ecological simulacrum. Urban For. Urban Green. 2018, 30, 152-156. [CrossRef]

111. Lawn \& Garden Pesticides Facts \& Figures. Beyond Pecticides. 2017. Available online: https://www. beyondpesticides.org/assets/media/documents/lawn/resources/bp-fact-lawnpesticides.081417.pdf (accessed on 14 November 2019).

112. WHO-World Health Organization. International Agency for Research on Cancer (IARC) Monographs Volume 112: Evaluation of Five Organophosphate Insecticides and Herbicides; IARC: Lyon, France, 2016.

113. Australia's Beloved Kangaroos Are Now Controversial Pests. National Geographic. Available online: https://www.nationalgeographic.com/magazine/2019/02/australia-kangaroo-beloved-symbolbecomes-pest/ (accessed on 10 November 2019).

114. Global Compendium of Weeds. The Top 12 Cited Invasive Weeds in the World. 2018. Available online: http://www.hear.org/gcw/species/cynodon_dactylon (accessed on 16 October 2019).

115. Meurk, C.D. Recombinant ecology of urban areas. In The Routledge Handbook of Urban Ecology; Douglas, I., Goode, D., Houck, M., Wang, R., Eds.; Routledge: Abingdon, UK, 2010.

116. McDonnell, M.J.; Hahs, A.K. The use of gradient analysis studies in advancing our understanding of the ecology of urbanizing landscapes: Current status and future directions. Landsc. Ecol. 2008, 23, 1143-1155. [CrossRef]

117. Zipperer, W.C. Factors Influencing Non-Native Tree Species Distribution in Urban Landscapes. In Urban Biodiversity and Design, Conservation Sciences and Practice Series; Müller, N., Werner, P., Kelcey, J.G., Eds.; Wiley-Blackwell Publishing: Hoboken, NJ, USA, 2010; pp. 243-251. [CrossRef]

118. Polsky, C.; Grove, J.M.; Knudson, C.; Groffman, P.M.; Bettez, N.; Cavender-Bares, J. Assessing the Homogenization of Urban Land Management with an Application to US Residential Lawncare. Proc. Natl. Acad. Sci. USA 2014, 111, 4432-4437. [CrossRef] [PubMed] 
119. Chapin, F.S.; Starfield, A.M. Time lags and novel ecosystems in response to transient climatic change in arctic Alaska. Clim. Chang. 1997, 35, 449-461. [CrossRef]

120. Botzat, A.; Fischer, L.K.; Kowarik, I. Unexploited opportunities in understanding liveable and biodiverse cities. A review on urban biodiversity perception and valuation. Glob. Environ. Chang. 2016, 39, 220-233. [CrossRef]

121. Heger, T.; Gessler, A.; Bernard-Verdier, M.; Greenwood, A. Towards an Integrative, Eco-Evolutionary Understanding of Ecological Novelty: Studying and Communicating Interlinked Effects of Global Change. BioScience 2019, 69, 888-899. [CrossRef] [PubMed]

122. Ignatieva, M.; Meurk, C.; Stewart, G. Low Impact Urban Design and Development (LIUDD): Matching urban design and urban ecology. Landsc. Rev. 2008, 12, 61-73.

123. Kabisch, N.; Korn, H.; Stadler, J.; Bonn, A. Nature-Based Solutions to Climate Change Adaptation in Urban Areas. Linkages between Science, Policy and Practice; Springer: Cham, Switzerland, 2017. [CrossRef]

124. Nesshoever, C.; Assmuth, T.; Irvine, K.J.; Rusch, G.M.; Waylen, K.A.; Delbaere, B.; Haase, D. The science, policy and practice of Nature-Based Solutions: An interdisciplinary perspective. Sci. Total Environ. 2017, 579, 1215-1227. [CrossRef]

125. Mangiafico, S.S.; Obropta, C.C.; Rossi-Griffin, E. Demographic Factors Influence Environmental Values: A Lawn-Care Survey of Homeowners in New Jersey. J. Ext. 2012, 50, 1 Rib6.

126. Xeriscaping with Texas Natives. Available online: https://www.gardensfortexas.com/xeriscaping-with-texasnatives (accessed on 1 November 2019).

127. A Woody Meadow in the Heart of the City. A Unique Research Project by the Universities of Melbourne and Sheffield Aims to Grow Urban Meadows That Are as Tough as They Are Beautiful by Claire Bolge. Available online: https://pursuit.unimelb.edu.au/articles/a-woody-meadow-in-the-heart-of-the-city (accessed on 15 October 2019).

128. Elmqvist, T.; Andersson, E.; Frantzeskaki, N. Sustainability and resilience for transformation in the urban century. Nat. Sustain. 2019, 2, 267-273. [CrossRef]

129. Elands, E.; Vierikko, K.; Andersson, E.; Fischer, L.K.; Goncalves, P.; Haase, D. Biocultural diversity: A novel concept to assess human-nature interrelations, nature conservation and stewardship in cities. Urban For. Urban Green. 2018, 40, 29-34. [CrossRef]

(C) 2020 by the authors. Licensee MDPI, Basel, Switzerland. This article is an open access article distributed under the terms and conditions of the Creative Commons Attribution (CC BY) license (http://creativecommons.org/licenses/by/4.0/). 